https://doi.org/10.15407/geotech2020.32.023

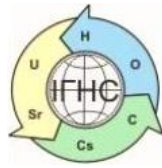

УДК 551.72 : 553.31 (477.63)

\title{
Покалюк В.В.
}

Покалюк В.В., докт. геол. наук, пров. н. с. ДУ «ГГНС НАНУ», https:/orcid.org/0000-0002-9282-0246, pvskan@ukr.net

\section{ЛІТОХІМІЯ І УМОВИ СЕДИМЕНТАЦІЇ ПАЛЕОПРОТЕРОЗОЙСЬКОЇ ЗАЛІЗИСТО-КРЕМЕНИСТО-СЛАНЦЕВОЇ ФОРМАЦІЇ КРИВОРІЗЬКОГО БАСЕЙНУ (УКРАЇНСЬКИЙ ЩИТ)}

У роботі на основі сучасних методів статистичної обробки масивів літохімічних даних уточнено особливості хімічного складу палеопротерозойської залізорудної (залізисто-кременисто-сланцевої) формації саксаганської світи Криворізького басейну Украӥнського щита у зв'язку із завданнями вдосконалення літохімічної систематики залізисто-кременистосланщевих формачій докембрію $і$ з 'ясування загальних палеогеографічних (кліматичних, фачіальних) умов їх кластогеннохемогенної седиментації. На серії бінарних діаграм проілюстровано взаємозв'язки між залізисто-кременистими і сланцевими породами формачії. Методом кластер-аналізу проведено літохімічну типізацію сланцевих порід залізистокременисто-сланцевої формації: виділено 12 елементарних кластерів, розділених між двома літохімічними групами $i$ чотирма підгрупами, індивідуалізованими за мінеральним складом. Позначено відповідності між літохімічними і мінеральними типами сланщевих порід. Сукупності літохімічних типів складають закономірну послідовність, яка відповідає вихідній аутигенно-мінеральній і аутигенно-літофачіальній зональності відкладів і дозволяє в загальних рисах позначити фачіальний ізоморфний ряд метаосадів від метакластогенних до метахемогенних. Запропоновано емпіричну класифікаиійну діаграму порід у координатах $\mathrm{Al}_{2} \mathrm{O}_{3}$ i $\left(\mathrm{Fe}_{2} \mathrm{O}_{3}+\mathrm{FeO}\right)$ за їхнім поділом на області кластогенної, кластогеннохемогенної і хемогенної седиментації. Найбільш багаті залізом породи - неокислені червонополосчаті джеспіліти - характеризуються найвищим співвідношенням $\mathrm{Fe}_{2} \mathrm{O}_{3} / \mathrm{FeO}$, що вказує на їхню седиментацію в мілководних добре аерованих умовах. Літохімічні ознаки порід у комплексі з особливостями їх залягання, стратифікаиії і поширення підтверджують в иілому протогумідний тип літогенезу в умовах рівнинних мілководних басейнів із субплатформним тектонічним режимом.

Ключові слова: палеопротерозой, залізисто-кременисто-сланцева формачія докембрію, Украӥнський щчит, Криворізький залізорудний басейн, літохімія

Вступ. Походження залізисто-кременисто-сланцевих формацій докембрію (ЗКФД), незважаючи на величезну кількість наукових праць на цю тему, залишається незмінно актуальною і остаточно не вирішеною фундаментальною проблемою геології докембрійських щитів. У рамках осадової концепції генезису, якої дотримується більшість фахівців, існує безліч варіантів, що по-різному оцінюють джерела речовини, фізико-хімічні механізми, тектонічні і фаціальні умови седиментації. Безперечні успіхи літохіміі у останні роки [40] показують важливість кількісних методів петрохімічної (літохімічної) систематики у вирішенні цих питань. Актуальність досліджень диктовано необхідністю вдосконалення літохімічної систематики залізисто-кременисто-сланцевих формацій докембрію і з'ясуванням загальних закономірностей їх кластогенно-хемогенної седиментації.

Об'єкт дослідження - палеопротерозойська залізорудна (залізисто-кременисто-сланцева) формація саксаганської світи Криворізького басейну (потуж- ність 1,5 км), що включає сім залізистих і сім сланцевих горизонтів (пачок).

Мета дослідження - на основі сучасних методів статистичної обробки масивів літохімічних даних уточнити хімічний склад основних різновидів порід палеопротерозойської залізорудної (залізистокременисто-сланцевої) формації саксаганської світи Криворізького басейну і отримати додаткові відомості про первинні палеогеографічні (кліматичні, фаціальні) умови седиментації осадів.

Завдання - систематизувати масив літохімічних даних із виділенням літохімічних типів порід, вивчити характер взаємозв'язків між ними.

Короткі відомості про геологічну будову Криворізького басейну і залізорудної формації саксаганської світи

Криворізький залізорудний басейн являє собою складчасту докембрійську синклінорну структуру субмеридіонального простягання протяжністю близь- 
ко 60 км при максимальній ширині складчастої зони до 7 км і максимальній глибині найбільш занурених частин близько 7 км. Стратиграфічний розріз Криворізького синклінорію $є$ найважливішим стратотипом раннього докембрію Українського щита (УЩ). У ві- ковому відношенні він охоплює інтервал мезоархейпалеопротерозой і за своїм представництвом та збереженістю не має собі рівних серед подібних розрізів інших регіонів і структур УЩ (рис. 1).

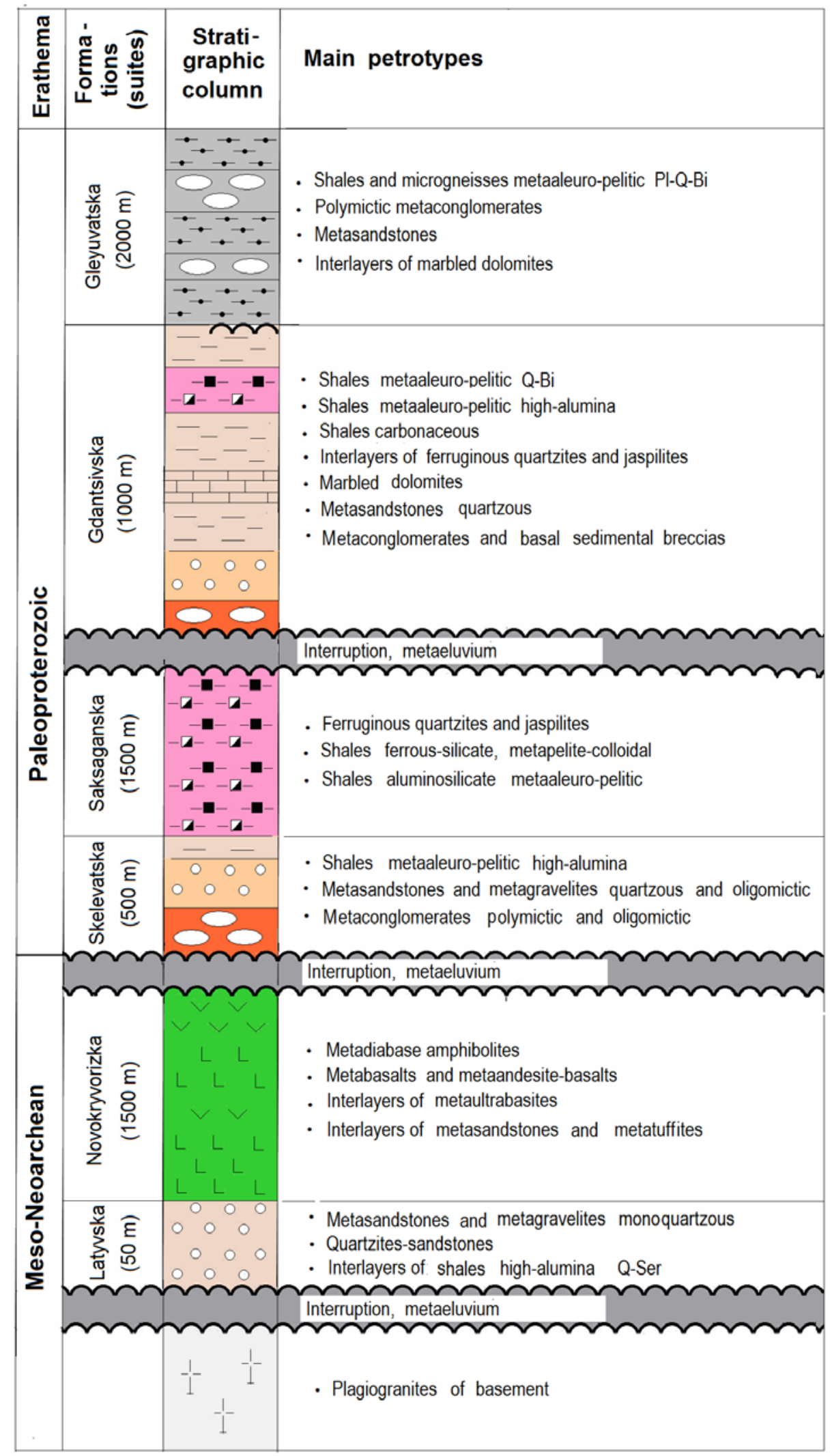

Рис. 1. Стратиграфічна колонка Криворізької синклінорної структури

Fig. 1. . Stratigraphic column of the Kryvyi Rig synclinor structure 
Стратиграфічний розріз синклінорію складають комплекси метаосадових та метавулканогенних порід, що залягають на архейському плагіогранітоїдному фундаменті (від низу до верху): 1 - латівська метатеригенна світа - метагравеліти, метапісковики, кварцити (потужність 10-60, зрідка до 200 м); 2 - новокриворізька метавулканогенна світа - метавулканіти основного і перехідного до середнього складів (потужність до 1500 м); 3 - скелюватська метатеригенна світа метаконгломерати, метагравеліти, метапісковики, метаалевропеліти; у верхах прошарки ультраосновних метавулканітів (потужність до 500 м); 4 - саксаганська метатеригенно-хемогенна (продуктивна залізорудна) світа - залізисті кварцити, сланці (потужність до 1500 м); 5 - гданцівська метахемогенно-теригенна світа - метапісковики, вуглисті сланці, доломіти, залізисті кварцити (потужність до 1100 м); 6 -глеєватська метахемогенно-теригенна світа - метапісковики, метаконгломерати, сланці, доломіти (потужність до 2000 м).

Найважливішою особливістю Криворізького синклінорію $є$ поєднання в його супракрустальному розрізі двох структурно-стратиграфічних поверхів/комплексів, розділених великою перервою та неузгодженістю: істотно вулканогенного мезонеоархейського («зеленокам'яного») і суттєво осадового палеопротерозойського. До нижнього структурного поверху відносяться латівська і новокриворізька світи, до верхнього - скелюватська, саксаганська, гданцівська і глеєватська світи.

Я.М. Белєвцевим [1] розроблено основу сучасної стратиграфії залізорудної саксаганської світи Кривбасу у вигляді семи сланцевих і семи залізистих горизонтів (товщ), що перешаровуються. Горизонти від першого сланцевого до другого залізистого включно складають нижню залізорудну підсвіту (потужність до 300 м). Середня (сланцева) підсвіта (потужність до 180 м) складається 3 третього і четвертого сланцевих горизонтів і розташованого між ними третього залізистого, який, проте, дуже часто випадає з розрізу. Верхню залізорудну підсвіту складають горизонти від четвертого до сьомого залізистих включно (потужність до 800 м). Склад і будова горизонтів відносно своєрідні, на підставі чого їх досить впевнено корелюють на роз'єднаних і віддалених одна від одної ділянках. Хемогенна природа залізистих кварцитів саксаганської світи і теригенна алевро-пелітова природа сланців, що з ними асоціюють, визнається більшістю дослідників, проте існують також альтернативні гіпотези, у тому числі космогенна і ендогенна.

Внутрішня будова світи, характер чергування/перешарування різних петротипів характеризуються аутигенно-мінералогічною зональністю, що $є$ невід'ємною рисою усіх палеопротерозойських залізисто-кременистих формацій світу. Ця зональність вира- жається у послідовному зменшенні кількості силікатів (i, відповідно, збільшенні оксидів заліза) від середини сланцевих горизонтів до середини залізистих, що відображає загальну схему зміни кластогенних осадів через кластогенно-хемогенні до хемогенних. Детальні дослідження залізорудної формації Кривого Рогу дали матеріал для виділення всередині залізистих і сланцевих горизонтів підлеглих ритмів - підгоризонтів і вивчення аутигенно-мінералогічної зональності [24, 25, 37]. У 1970-х роках Ю.Г. Гершойг, Р.Л. Грицай, М.В. Педан, В.О. Шапошніков, О.С. Журавльов, M.I. Черновський, Е.В. Дмитрієв та інші дослідники провели стратиграфічне розчленовування всіх залізистих горизонтів саксаганської світи, виявили закономірності мінливості потужностей, мінерального і хімічного складу горизонтів за простяганням і у вертикальному розрізі $[8,10,11,16]$.

\section{Основи літохімічної систематики залізисто- кременистих (залізисто-кременисто-сланцевих) формацій докембрію (ЗКФД). Стан питання та шляхи подальшого розвитку}

Загальний хімічний склад порід ЗКФД різко відрізняється від складу інших метаосадових або ендогенних порід. Основною їх рисою $є$ різке переважання заліза та кремнію над іншими петрогенними компонентами (сума оксидів заліза і кремнію становить 80100\%). Складність і різноманіття літологомінералогічних та літолого-хімічних типів порід, що зустрічаються в складі ЗКФД саксаганської світи Кривбасу, визначилися накладенням і взаємовпливом двох процесів - кластогенного і хемогенного накопичення осадів, що визначили широкий спектр перехідних і змішаних порід.

Найбільш повне зібрання хімічних аналізів і відомостей $з$ літохімічної систематики порід саксаганської світи міститься у колективних монографіях [7, 16, 33].

У літохімічній систематиці залізисто-кременистих порід України найчастіше використовується систематика, запропонована М.П. Семененком [31, 32], за якої ці породи поділяються на рудні, малорудні і нерудні по співвідношенням коефіцієнтів А (глиноземистості), F (залізистості), М (магнезіальності), С (вапнистості) і О (коефіцієнту окислення). Сума перших чотирьох компонентів, розрахованих у молекулярних кількостях, приймається за 100\%.

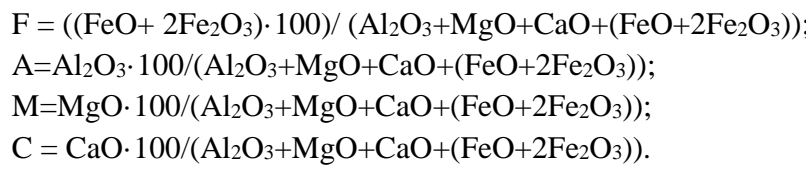

Оскільки коефіцієнт залізистості не відображає мінералогічної форми закисного заліза, яке може зв'язуватися у великій кількості в карбонатах, силіка- 
тах і т.д., вводиться додатковий коефіцієнт окислення $\mathrm{O}=\mathrm{Fe}_{2} \mathrm{O}_{3} / \mathrm{FeO}$. Якщо порода складається 3 гематиту, магнетиту і кварцу, то коефіцієнт окислення іiі буде вищий за одиницю. За наявності у породі тільки кварцу і магнетиту коефіцієнт окислення дорівнює одиниці, а у присутності залізистих силікатів він буде менший за одиницю. Коефіцієнт окислення є одним із найважливіших у систематиці залізисто-кременистих порід. Залежно від цього коефіцієнту і загального вмісту заліза виділяють наступні групи вторинно неокислених порід: 1) закисно-окисні рудні (магнетитгематитові), 2) окисно-закисні рудні (магнетитові), 3) окисно-закисні малорудні (магнетит-силікаткарбонатні ), 4) закисні бідні (магнетит-силікаткарбонатні), 5) закисні нерудні (карбонатні і силікатні) [16]. Зазначеним групам приблизно відповідають найменування порід, що часто використовуються в геологічній практиці, однак не строго визначені у літолого-мінералогічному та термінологічному відношеннях: 1) залізисті червонополосчаті кварцити або джеспіліти, 2) залізисті сірополосчаті кварцити, 3) залізисті сірополосчаті джеспери/роговики, 4 ) залізисті сланці, 5) алюмосилікатні сланці.

Хімічний склад порід ЗКФД саксаганської світи закономірно змінюється в розрізі пластів і горизонтів (аутигенно-літохімічна зональність, тісно пов'язана 3 аутигенно-мінералогічною зональністю): у напрямку від сланцевих горизонтів до залізо-кремнієвих збільшується вміст загального і тривалентного заліза; зменшується кількість $\mathrm{SiO}_{2}, \mathrm{Al}_{2} \mathrm{O}_{3}, \mathrm{~K}_{2} \mathrm{O}, \mathrm{TiO}_{2}$, рідкісних і розсіяних елементів. Докладний аналіз загальних закономірностей аутигенно-літохімічної зональності при переході від сланцевих порід до залізистих наведено Р.Л. Грицаєм в роботі [16] на прикладі третьогочетвертого сланцевих і четвертого залізистого горизонтів Новокриворізького родовища. Було розглянуто також статистичні параметри розподілу та кореляційні зв'язки основних петрохімічних компонентів і елементів-домішок. Досить детально досліджено закономірності розподілу петрогенних і малих елементів у залізисто-кременисто-сланцевій формації Курської магнітної аномалії (КМА) [26; 27].

Завдання подальшого розвитку літохімічної систематики порід ЗКФД ми бачимо у деталізації петрохімічних груп М.П. Семененка методами багатовимірної статистики (кластерний аналіз), позначенні відповідностей між літохімічними та мінералогічними типами порід, виявленні часткових закономірностей аутигенно-літохімічної зональності.

\section{Фактичний матеріал і методика}

Методологічною і теоретичною основою нашого вивчення стали уявлення про відносну ізохімічність регіонального метаморфізму низьких і помірних ступенів для більшості петрогенних і малих елементів
(В.К. Головенок, 1973; М.Л. Добрецов та ін., 1970; О.О Маракушев та ін., 1986; О.О. Предовський, 1970, 1980; О.М. Нейолов, 1980; та ін.). Для літохімічного вивчення порід саксаганської світи було використано вибірку 211 повних хімічних аналізів, зібрану з опублікованих та фондових джерел $[3,7,12,13,16,17,19$, $23,33,34]$. До вибірки увійшли основні різновиди порід саксаганської світи під найменуваннями, які використані у першоджерелах; поряд 3 аналізами одиничних проб використано також групові проби і середні дані по горизонтам та підгоризонтам. Найбільш детально у вибірці вивчено склад сланцевих порід, що несуть ознаки кластогенної седиментації. На жаль, відсутні дані з хімізму метапісковиків, що зрідка зустрічаються всередині розрізу саксаганської світи в Кременчуцькій структурі. Літохімічна систематизація та типізація проведені на основі кластераналізу і за допомогою серії додаткових бінарних діаграм.

\section{Результати}

Загальні особливості і взаємозв'язки хімічного складу залізисто-кременистих і сланцевих порід саксаганської світи добре ілюструються серією бінарних петрохімічних діаграм (рис. 2). Всю сукупність порід світи на цих діаграмах показано нами у складі чотирьох найбільш загальних літолого-мінералогічних груп: 1 - нерудні сланці алюмосилікатні, переважно серицитові ( \pm Бі, Хл, Грф, Ствр, Гр ${ }^{2}$ ); 2 - малорудні і нерудні сланці залізисто-силікатні, переважно біотитові, хлоритові та амфіболові, здебільшого змішаного (Бі, Хл, Амф) складу ( \pm Гр, Карб, Грф); 3 - роговики, кварцити, джеспери, яшмо-сланці (кварцито-сланці) рудні і малорудні, силікатно-магнетитові, магнетитсилікатні (土 Карб); 4 - рудні залізисті кварцити і джеспіліти (магнетитові, гематит-магнетитові, \pm Кумм). Перша і друга групи домінують у складі сланцевих горизонтів, третя і четверта - у складі залізистих горизонтів. У загальному наближенні, 1-2 і 3-4 групи характеризують, відповідно, склад сланцевих і залізистих горизонтів.

Бінарні діаграми (рис. 2) добре ілюструють зміни вмісту основних хімічних компонентів при переході від сланцевих порід (горизонтів) до залізистих у послідовному ряді: алюмосилікатні сланці $\rightarrow$ залізистосилікатні сланці $\rightarrow$ малорудні і рудні сіроколірні джеспери силікатно-магнетитові, магнетит-силікатні ( карб) $\rightarrow$ рудні магнетитові, гематит-магнетитові кварцити, джеспіліти.

${ }^{2}$ Скорочення найменувань мінералів: Кв - кварц, Сц - серицит, Бі - біотит, Хл - хлорит, Грф - тонкодисперсний графіт, Ствр - ставроліт, Гр - гранат, Карб - карбонат, Амф амфібол, Кумм - куммінгтоніт 
У зазначеному ряді послідовно зменшується вміст $\mathrm{Al}_{2} \mathrm{O}_{3}, \mathrm{SiO}_{2}, \mathrm{~K}_{2} \mathrm{O}, \mathrm{TiO}_{2}$. Вміст $\mathrm{Na}_{2} \mathrm{O}$ також зазнає загального зменшення, однак воно виражене менш чітко i має відхилення, пов'язані з наявністю серед руднихмалорудних джесперів і залізистих сланців окремих проб із відносно підвищеним вмістом $\mathrm{Na}_{2} \mathrm{O}$ ( 1\%). Значення $\mathrm{Fe}_{2} \mathrm{O}_{3}, \mathrm{FeO}, \mathrm{MgO}, \mathrm{MnO}, \mathrm{CaO}, \mathrm{P}_{2} \mathrm{O}_{5}, \mathrm{CO}_{2}$ в цілому нерівномірно зростають, відхиляючись від прямої залежності. Відхилення ці пов'язані з тим, що вміст $\mathrm{FeO}, \mathrm{MgO}, \mathrm{MnO}$ в багатих магнетитових кварцитах, рудних і мало рудних джесперах є близьким; вміст $\mathrm{CaO}$ має відносний максимум в мало рудних джесперах; вміст $\mathrm{CO}_{2}$ різко падає в багатих магнетитових кварцитах при максимумі в рудних і мало рудних джесперах; у окремих різновидах залізистосилікатних сланців вміст $\mathrm{FeO}$ i $\mathrm{MgO} \epsilon$ вищім, ніж в рудних і мало рудних джесперах; вміст $\mathrm{Fe}_{2} \mathrm{O}_{3}$ різко зростає в рудних силікатно-магнетитових джесперах, y багатих магнетитових i, особливо, в гематитмагнетитових кварцитах. Вміст сірки в цілому є низьким (до 0,5\%), іноді підвищуючись до 1-3\% в сірокольорових джесперах і залізисто-силікатних сланцях. Фундаментальною особливістю хімізму порід, успадкованою від вихідних осадів, є різке збільшення коефіцієнту окислення $\mathrm{Fe}_{2} \mathrm{O}_{3} / \mathrm{FeO}$ у незмінених гіпергенезом багатих залізистих кварцитах i, особливо, в найбільш багатих гематитвмісних кварцитах у порівнянні з малорудними і безрудними джесперами і сланцями. Ця особливість цілком виразно вказує на закисно-окисні умови седиментації для перших (більше мілководні) і закисні - для других.

За даними Р.Л. Грицая [16], максимальний вміст карбонатів (магнезіально-залізистих) встановлено в пачках магнетит-хлорит-карбонатних джесперів (25\%), перехідних між сланцевими і залізистими горизонтами; він закономірно зменшується до 3-5\% до середини сланцевих і залізистих горизонтів. Цим ми пояснюємо підвищений вміст оксидів, зв'язаних у карбонатах (FeO, $\mathrm{MgO}, \mathrm{MnO}, \mathrm{CaO}, \mathrm{P}_{2} \mathrm{O}_{5}, \mathrm{CO}_{2}$ ) у групі перехідних кластогенного-хемогенних фацій залізистих порід. До цієї ж перехідної групи приурочений відносно підвищений вміст вуглецю і сірки.

Характерно, що чисті хемогенні осади, особливо багаті залізорудні фації, що представлені магнетитовими і гематит-магнетитовими кварцитами, практично позбавлені вільного вуглецю [21], сліди якого 3'являються тільки при додаванні теригенної складової. Цей факт входить у деяке протиріччя з біохіміч- ної гіпотезою осадження заліза, коли періодичні «сплески» цвітіння фітопланктону мали б приводити до окислення $\mathrm{Fe}^{2+}$ до $\mathrm{Fe}^{3+}$ безпосередньо у товщі води i подальшого осадження нерозчинного гідроксиду заліза. Зазначена особливість хімізму свідчить про просторове i/або часове розділення фацій залізонакопичення і фацій, збагачених тонкодисперсною органікою.

Найбільш показовими у вищевказаному літологопетрохімічному ряді є зміни за $\mathrm{Al}_{2} \mathrm{O}_{3} \mathrm{i}\left(\mathrm{Fe}_{2} \mathrm{O}_{3}+\mathrm{FeO}\right)-$ компонентами, що зазнають максимальної диференціації (крім $\mathrm{SiO}_{2}$ ). На бінарній діаграмі цих компонентів фігуративні точки порід вишикуються у вигляді чіткого тренду, близького до прямої залежності з послідовною зміною одного літолого-петрохімічного типу (члена фаціально-геохімічного ряду) іншим. Це дозволяє нам використовувати дану діаграму для класифікаційних цілей (розмежування основних літологопетрохімічних типів або груп порід). У якості границі між сланцевими і залізо-кременистими породами, 3 певною долею умовності, враховуючи в цілому поступовість переходу і перекриття полів, може бути прийнято лінію розділу $\mathrm{Al}_{2} \mathrm{O}_{3} /\left(\mathrm{Fe}_{2} \mathrm{O}_{3}+\mathrm{FeO}\right)=0,6$. Сланцеві породи, що потрапляють в сектор III зі значеннями $\mathrm{Al}_{2} \mathrm{O}_{3} /\left(\mathrm{Fe}_{2} \mathrm{O}_{3}+\mathrm{FeO}\right)=0,3-0,6$, мають перехідний склад до малорудних магнетит-силікатних джесперів. 3 границею 0,6 також пов'язана поява істотно амфіболових (куммінгтонітових) різновидів сланців, типових у складі силікат-магнетитових джесперів, магнетитових кварцитів. Ця границя може бути прийнята також у якості переходу від істотно кластогенної седиментації алюмосилікатних і залізистосилікатних метапелітів, основними мінералами яких є серицит, біотит, рідше хлорит, до змішаної кластогенно-хемогенної седиментації джесперів. Ця ж границя добре виражена на діаграмі $\left(\mathrm{Fe}_{2} \mathrm{O}_{3}+\mathrm{FeO}\right)-\mathrm{SiO}_{2}$, відповідаючи лінії розділу $\mathrm{SiO}_{2} /\left(\mathrm{Fe}_{2} \mathrm{O}_{3}+\mathrm{FeO}\right) \approx 2,5$ (рис. 3).

Границя $\mathrm{Al}_{2} \mathrm{O}_{3} /\left(\mathrm{Fe}_{2} \mathrm{O}_{3}+\mathrm{FeO}\right)=0,3$ відображає перехід від змішаної кластогенно-хемогенної седиментації до істотно хемогенної. Вона ж чітко проявлена на діаграмі $\left(\mathrm{Na}_{2} \mathrm{O}+\mathrm{K}_{2} \mathrm{O}\right)-\mathrm{Al}_{2} \mathrm{O}_{3}$, відповідаючи приблизно $2 \%$ суми лугів. Отже, сектору I - II на рис. 3 відповідають області переважно кластогенної седиментації, сектор III - області змішаної кластогеннохемогенної седиментації, сектори IV-V - області переважно хемогенної седиментації. 

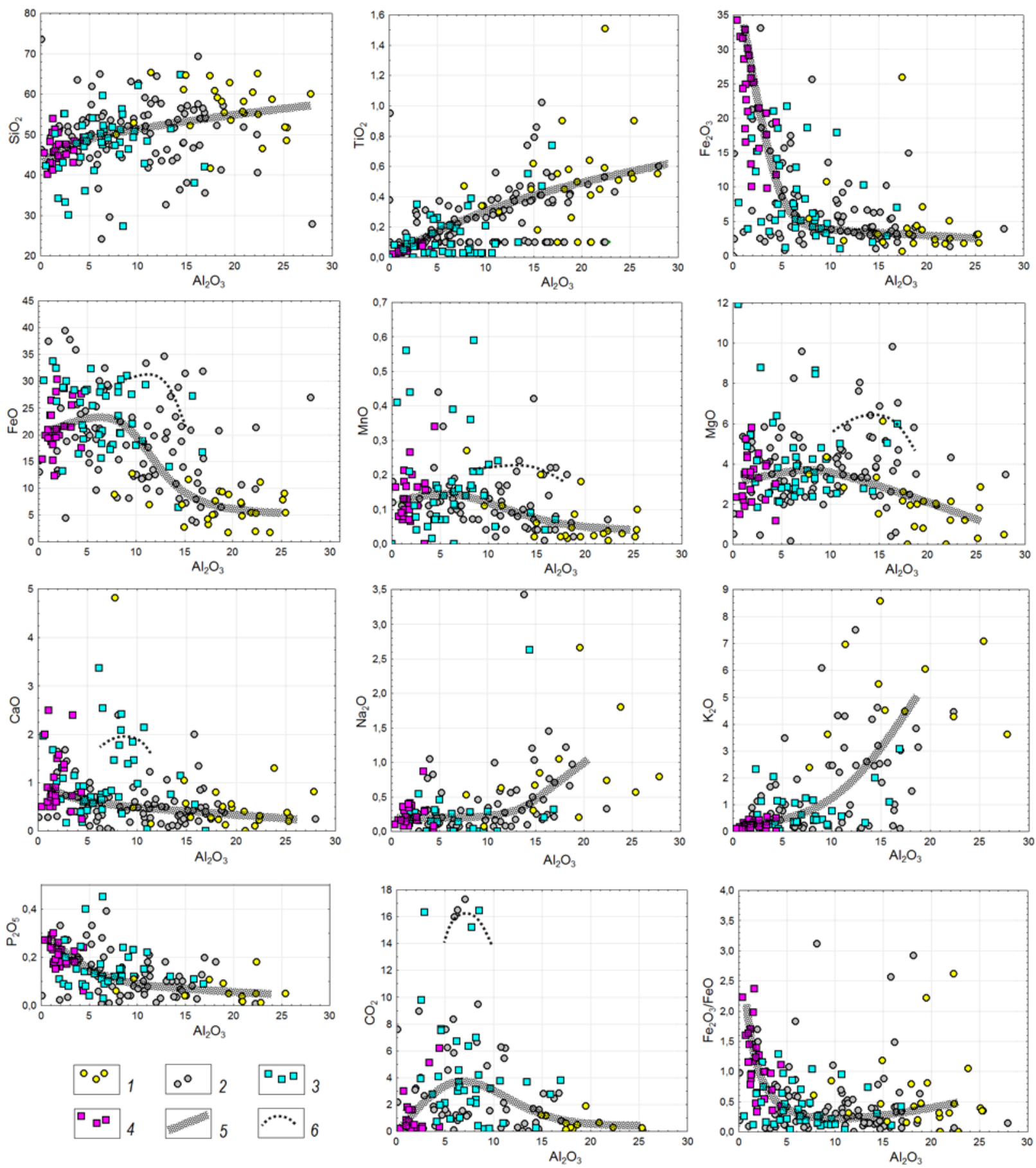

Рис. 2. Основні тенденції змін хімічного складу порід залізисто-кременисто-сланцевої формації саксаганської світи Кривбасу на серії бінарних петрохімічних діаграм у послідовному літохімічному ряді метаосадів $1 \leftrightarrow 2 \leftrightarrow 3 \leftrightarrow 4$.

1 - нерудні сланці алюмосилікатні, істотно серицитові ( \pm Бі, Хл, Грф, Ствр, Гр); 2 - малорудні і нерудні сланці залізистосилікатні - біотитові, хлоритові, амфіболові ( \pm Грн, Карб, Грф); 3 - малорудні і рудні роговики, кварцити, джеспери, яшмосланці, кварцито-сланці (силікатно-магнетитові, магнетит-силікатні, магнетит-силікат-карбонатні, силікат-карбонатмагнетитові); 4 - рудні залізисті кварцити і джеспіліти (магнетитові, гематит-магнетитові, \pm Кумм); 5 - основні тенденції; 6 - другорядні тенденції.

Fig. 2. The main tendencies of the changes in the chemical composition of the rocks of the Saksagan iron-siliceous-shale Formation of the Kryvyi Rig basin on a series of binary diagrams in the sequential lithochemical series $1 \leftrightarrow 2 \leftrightarrow 3 \leftrightarrow 4$.

1 - non-iron shales - aluminosilicate, substantially sericitic ( \pm Bt, Chl, Gr, St, Grt); 2 - slightly iron and non-iron schists - ironsilicate, biotite, chlorite, amphibole ( \pm Grt, $\mathrm{Cb}, \mathrm{Gr}$ ); 3 - slightly iron and iron hornfelses, quartzites, jespers, jasper schists, quartzite schists (silicate-magnetite, magnetite-silicate, magnetite-silicate-carbonate, silicate-carbonate-magnetite); 4 - rich-iron quartzites and jespilites (magnetite, hematite-magnetite, \pm Cum); 5 - main trends; 6 - minor trends.

Note: 1 - essentially sericite schists (Ser, Chl-Ser, Ser-Bt), 2 - essentially biotite schists (Bt, Chl-Bt), 3 - essentially chlorite schists (Chl, Cb-Chl, Bt-Chl), 4 - essentially amphibole schists (Cum, Grt-Cum, Bt-Cum, Chl-Amph). In parentheses is the number of analyzes. 

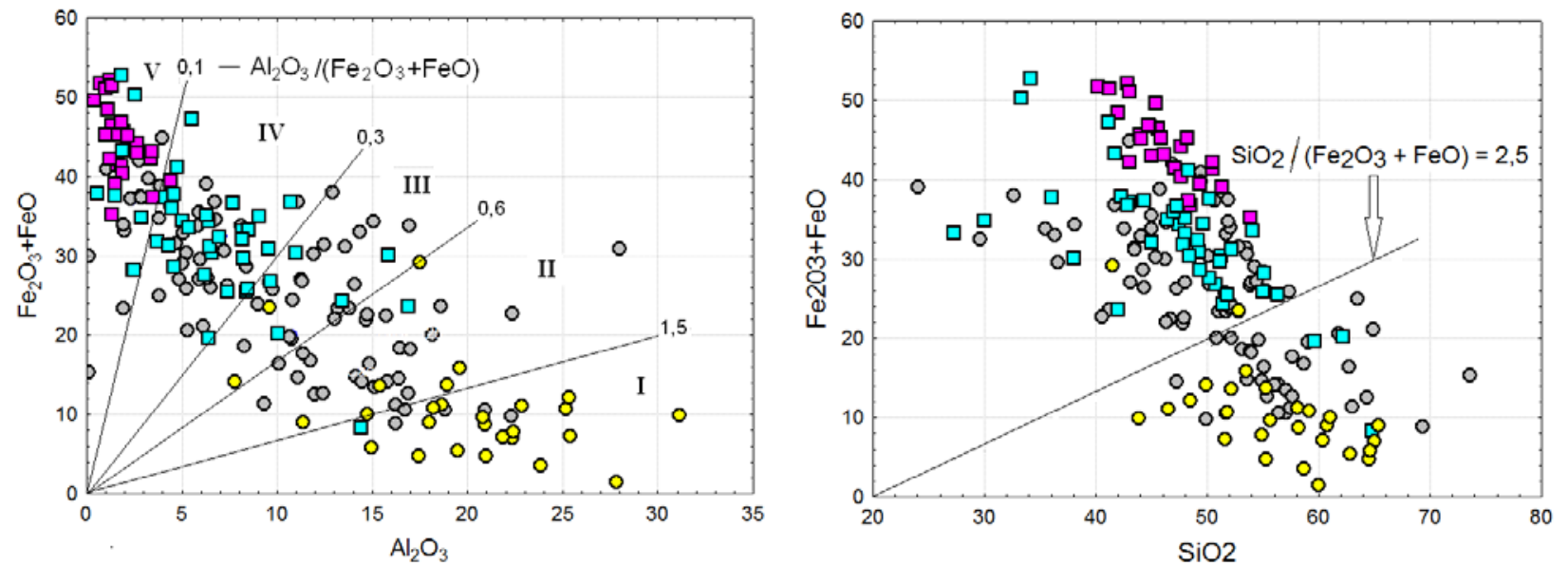

Рис. 3. Розмежування основних генетичних і літолого-петрохімічних типів залізисто-кременисто-сланцевих порід саксаганської світи на фаціально-геохімічних трендах у координатах: $\left(\mathrm{Fe}_{2} \mathrm{O}_{3}+\mathrm{FeO}\right)$ і $\mathrm{Al}_{2} \mathrm{O}_{3}$ (зліва); $\left(\mathrm{Fe}_{2} \mathrm{O}_{3}+\mathrm{FeO}_{\text {) }}\right.$ i $\mathrm{SiO}_{2}$ (праворуч). Сектори: I - II - переважно кластогенної седиментації, III - змішаної кластогенно-хемогенної седиментації, IV-V - переважно хемогенної седиментації. Умовні позначення див. на рис. 2.

Fig. 3. Differentiation of the main genetic and lithological-petrochemical types of rocks of the Saksagan iron-siliceous Formation on the facies-geochemical trends in the coordinates: (Fe2O3 + FeO) and Al2O3 (left); (Fe2O3+FeO) and SiO2 (right).

Sectors: I - II - predominantly clastogenic sedimentation, III - mixed clastogenic-chemogenic sedimentation, IV - V - predominantly chemogenic sedimentation. Legend see fig. 2.

Таблиця 1. Середній склад мінералогічних типів сланців саксаганської світи (вибірки сформовано за формальномінералогічним принципом)

Table 1. The average composition of the mineralogical types of shale rocks of the Saksagan Formation

\begin{tabular}{|c|c|c|c|c|}
\hline & 1 & 2 & 3 & 4 \\
\hline & (26) & (17) & (11) & (27) \\
\hline $\mathrm{SiO}_{2}$ & 56,25 & 52,37 & 53,91 & 48,60 \\
\hline $\mathrm{TiO}_{2}$ & 0,49 & 0,29 & 0,27 & 0,29 \\
\hline $\mathrm{Al}_{2} \mathrm{O}_{3}$ & 20,19 & 13,88 & 12,15 & 9,17 \\
\hline $\mathrm{Fe}_{2} \mathrm{O}_{3}$ & 3,93 & 3,97 & 5,99 & 5,24 \\
\hline $\mathrm{FeO}$ & 6,19 & 15,33 & 13,57 & 25,37 \\
\hline $\mathrm{Fe}_{2} \mathrm{O}_{3}+\mathrm{FeO}$ & 10,11 & 19,30 & 19,56 & 30,61 \\
\hline $\mathrm{MnO}$ & 0,06 & 0,13 & 0,13 & 0,14 \\
\hline $\mathrm{MgO}$ & 2,18 & 4,56 & 4,20 & 4,52 \\
\hline $\mathrm{CaO}$ & 0,45 & 0,47 & 0,59 & 0,58 \\
\hline $\mathrm{Na}_{2} \mathrm{O}$ & 0,60 & 0,43 & 0,55 & 0,40 \\
\hline $\mathrm{K}_{2} \mathrm{O}$ & 4,37 & 1,75 & 2,22 & 1,20 \\
\hline $\mathrm{Na}_{2} \mathrm{O}+\mathrm{K}_{2} \mathrm{O}$ & 4,97 & 2,18 & 2,77 & 1,60 \\
\hline $\mathrm{P}_{2} \mathrm{O}_{5}$ & 0,07 & 0,14 & 0,08 & 0,15 \\
\hline S сульф & 0,38 & 0,29 & 0,12 & 0,38 \\
\hline SOззагальн & 0,19 & 0,14 & & 0,51 \\
\hline $\mathrm{CO}_{2}$ & 0,60 & 1,52 & 2,30 & 1,15 \\
\hline С вільн. & 0,69 & & & \\
\hline В.п.п. & 4,35 & 4,51 & 5,86 & 3,56 \\
\hline$\sum$ & 100,97 & 99,78 & 101,93 & 101,27 \\
\hline
\end{tabular}

Примітка: 1 - сланці суттєво серицитові (Сц, Хл-Сц, Сц-Бі), 2 - сланці суттєво біотитові (Бі, Хл-Бі), 3 - сланці суттєво хлоритові (Хл, Карб-Хл, Бі-Хл), 4 - сланці суттєво амфіболові (Кумм, Гр-Кумм, Бі-Кумм, Хл-Амф). У дужках - кількість аналізів.

Петрохімічна типізація метакластогенних сланцевих порід саксаганської світи

Основний інтерес для палеофаціальних та інших реконструкцій на етапі саксаганської світи представляють нерудні і малорудні сланці, основна маса яких відображає кластогенну складову на етапі седиментації залізорудної саксаганської світи. Теригеннокластичне джерело основної маси сланцевих шарів підтверджується наявністю у їх хімічному складі прямої кореляції між $\mathrm{Al}$, Ti, К. Між тим, допускається, що деяка частина сланцевих прошарків, збагачених натрієм (прошарки, що містять альбіт, стільпномелан), утворилися за участю вулканокластичного попілового матеріалу [19, 41]. Крім того, припускається, що глинозем у сланцях і залізистих кварцитах може мати, хоча б частково, і хемогенне осадження. 
Прошарки сланців більш-менш однорідного мінералогічного складу зустрічаються в усіх горизонтах саксаганської світи (як сланцевих, так і залізистих). Певний виняток становить тільки п'ятий залізистий горизонт, представлений джеспілітами, в якому прошарки сланців практично відсутні. Цей горизонт характеризується також найбільш високим вмістом заліза (середній вміст $\left.\mathrm{Fe}_{\text {заг. }}=39 \%\right)$.

Згідно Я.М. Белевцева, з петрохімічної точки зору сланці саксаганської світи може бути розділено на два типи: алюмосилікатні та залізисто-силікатні. У хімічному складі перших з них вміст $\mathrm{SiO}_{2}$ становить у середньому 60\%; $\mathrm{Al}_{2} \mathrm{O}_{3}-25-30 \%$; заліза (у формі обох оксидів) міститься до 5\%. Залізисто-силікатні сланці мають $30-50 \% \mathrm{SiO}_{2}$, загального заліза - 30-45\%, $\mathrm{Al}_{2} \mathrm{O}_{3}$ - близько 15\%. Крім цих двох типів П.П. Назаров [7] виділяє ще перехідний тип від алюмосилікатних сланців до залізисто-силікатних.

До числа алюмосилікатних сланщів відносяться (за П.П. Назаровим [7]) такі мінералогічні типи: кварцево-серицитові і кварц-біотит-серицитові (із переважанням серициту над біотитом). В них часто присутні тонкорозсіяний графіт, акцесорний турмалін, лейкоксен, пірит. Іноді в змінних кількостях в них розвинений карбонат (сидерит-сидероплезит) і блідо-зелений хлорит.

Для залізисто-силікатних сланц̧ів характерна відсутність калієво-алюмінієвої слюди (мусковіту, серициту). Породоутворюючими мінералами в них зазвичай є біотит, залізистий хлорит (афросидерит), нерідко амфібол типу куммінгтоніту-грюнериту та порфіробластичний магнетит; у невеликих кількостях зустрічаються кварц, графітитовий пил; може бути присутнім залізистий карбонат. Акцесорні мінерали дуже рідкісні, з них зустрічаються: циркон, турмалін, лейкоксен, апатит (все у вигляді дуже дрібних зерен), пірит. За мінералогічним складом серед залізистосилікатних сланців можна виділити такі різновиди: Кв-Бі, Кв-Хл, Кв-Хл-Бі, Кв-Бі-Хл, Бі-Грф-Хл. У кожній 3 цих різностей можуть бути присутні магнетит $\mathrm{i}$ куммінгтоніт (у вигляді порфіробластів, незалежно один від одного), а також сидерит. Прошарки залізисто-силікатних сланців зустрічаються в усіх горизонтах залізорудної формації.

На серії бінарних діаграм (рис. 4) є можливість детальніше, ніж це відображено на рис. 1, зупинитися на взаємовідносинах хімічного складу різних мінералогічних типів сланцевих порід саксаганської світи. В цілому підтверджується поділ усієї сукупності сланцевих порід на дві групи: алюмосилікатну і залізистосилікатну. Перехід між ними дещо різкий; наявність проміжної групи, порівнянної за кількістю проб із вищеназваними, не підтверджується, хоча, безумовно, ряд проб має перехідний склад. Дуже яскраво відмін- ності між групами проявлені насамперед за вмістом $\mathrm{Al}_{2} \mathrm{O}_{3}, \mathrm{MgO}, \mathrm{FeO}, \mathrm{TiO}_{2}, \mathrm{~K}_{2} \mathrm{O}$ (рис. 4).

До групи алюмосилікатних сланців входять сланці істотно серицитові (Кв-Сц, Кв-Хл-Сц, Кв-Бі-Сц, КвСц-Бі). В них встановлюється чітка негативна кореляція між $\mathrm{Al}_{2} \mathrm{O}_{3}$ i $\mathrm{SiO}_{2}$, що свідчить про значну домішку алевритових кварцових частинок. Діапазон значень $\mathrm{Al}_{2} \mathrm{O}_{3}$ в них дещо широкий i варіює для більшості проб від 15 до 30\%. 3 огляду на цей діапазон, серед них можна виділити дві-три підмножини із середніми значеннями $\mathrm{Al}_{2} \mathrm{O}_{3} \sim 15,20$ (домінують) і 25\%.

Для залізисто-силікатної групи сланців характерною є значна диференціація складу. Вмісти $\mathrm{Al}_{2} \mathrm{O}_{3}$ знаходяться у межах 4-15\%, FeO - 10-40\%, MgO - 2,5$7 \%$. В істотно біотитових сланцях ще помітний негативний зв'язок між $\mathrm{Al}_{2} \mathrm{O}_{3}$ i $\mathrm{SiO}_{2}$, тоді як в істотно хлоритових і куммінгтонітових він вже не простежується. Це говорить про домішки алевритового кварцу в перших і відсутності його у других (тонко пелітовому вихідному складі). За вмістом $\mathrm{FeO}$ залізисто-силікатні сланці поділяються на дві підгрупи: 1) $\mathrm{FeO}=10-25 \%$; 2) $\mathrm{FeO}=25-40 \%$. Перша підгрупа домінує. До неї входять як істотно хлоритові, так і істотно біотитові, а також частина куммінгтонітових сланців; друга ж, більш залізиста група, представлена майже виключно куммінгтонітовими сланцями, які асоціюють з рудними силікатно-магнетитовими кварцитами. Крім $\mathrm{FeO}$ зазначені підгрупи розрізняються за $\mathrm{SiO}_{2}, \mathrm{Al}_{2} \mathrm{O}_{3}, \mathrm{TiO}_{2}$, $\mathrm{CO}_{2}$, В.п.п. (вміст усіх цих компонентів в куммінгтонітових сланцях нижче); вміст $\mathrm{Fe}_{2} \mathrm{O}_{3}, \mathrm{MnO}, \mathrm{MgO}$, $\mathrm{CaO}, \mathrm{P}_{2} \mathrm{O}_{5}$ зазнає незначних коливань. Істотно біотитові і істотно хлоритові сланці за хімічним складом у цілому досить близькі і майже не розрізняються; хлоритові сланці більш карбонатисті, що виражається підвищеним вмістом в них $\mathrm{CO}_{2}$.

За даними Р.Л. Грицая [16], поява амфіболів (куммінгтоніту) у складі залізистих горизонтів пояснюється локальними підвищеннями на окремих ділянках навіть у межах одного родовища ступеня метаморфізму порід. При цьому біотит-хлоритові парагенезиси змінюються біотит-куммінгтонітовими. Не заперечуючи цих висновків, ми вважаємо, що поряд із підвищенням метаморфізму порід на появу куммінгтоніту істотно впливає вихідний більш залізистий хімічний склад осадів, що відкладалися.

Хімічний і мінеральний склад сланцевих шарів тісно парагенетично пов'язаний із хімізмом асоціюючих хемогенних залізисто-кременистих шарів. Чим вище вміст $\mathrm{FeO}$ в залізистих кварцитах, тим вище залізистість силікатних сланцевих шарів, що 3 ними асоціюють. 

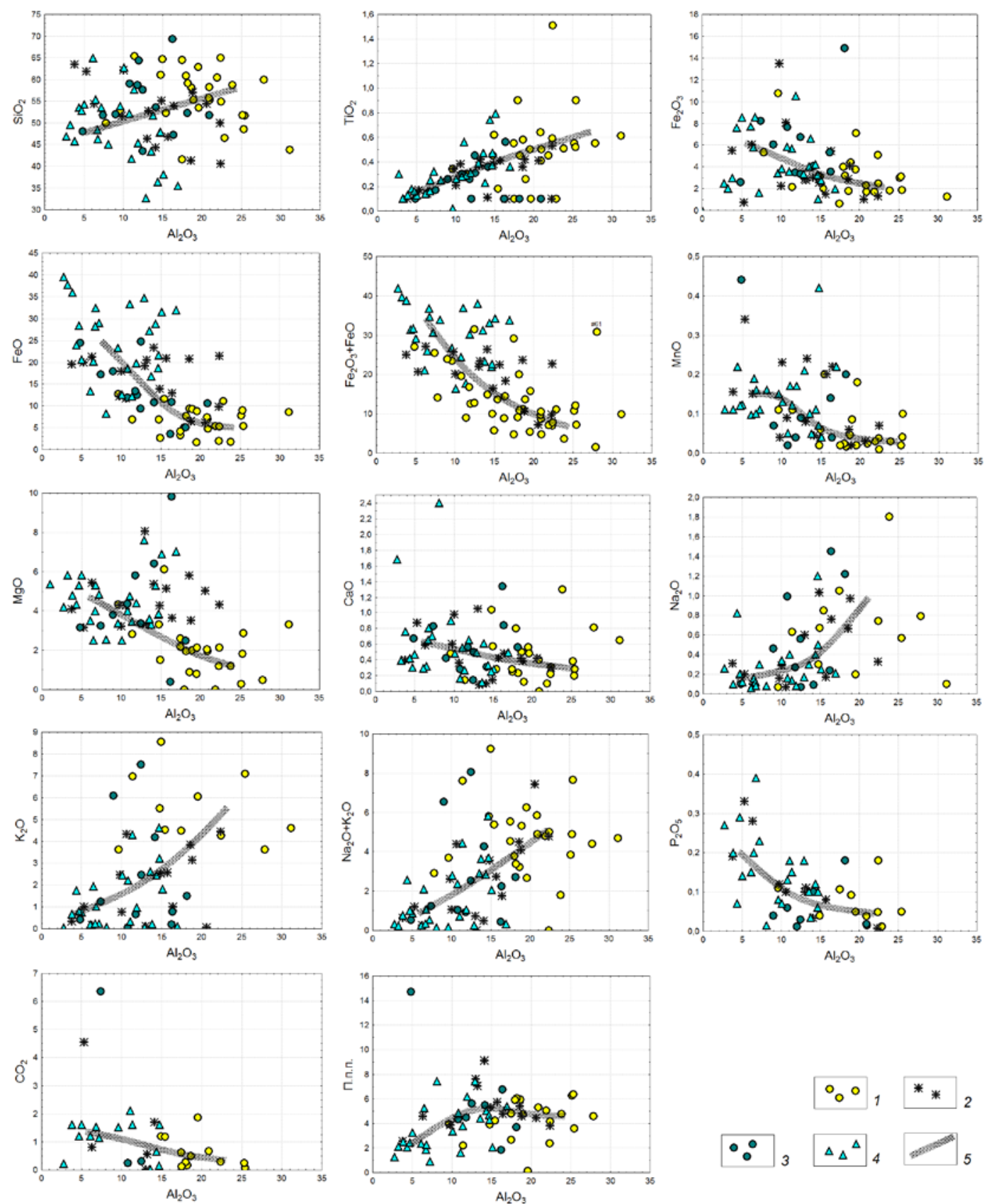

Рис. 4. Основні тенденції змін хімічного та мінерального складу сланцевих порід ЗКФД саксаганської світи Кривбасу на серії бінарних петрохімічних діаграм.

1 - сланці істотно серицитові (Кв-Сц, Кв-Хл-Сц, Кв-Бі-Сц, Кв-Сц-Бі); 2 - сланці істотно біотитові (Бі, Кв-Бі, Хл-Бі); 3 - санці істотно хлоритові (Хл, Бі-Хл, Карб-Хл); 4 - сланці істотно амфіболові (Кумм, Гр-Кумм, Гр-Бі-Кумм, Бі-Кумм, Хл-Кумм); 5 - тренд зміни складу.

Fig. 4. The main tendencies of changes in the chemical and mineral composition of shale rocks of the Saksagan iron-siliceous-shale Formation in the Kryvyi Rig basin on a series of binary diagrams.

1 - essentially sericite schists (Qz-Ser, Qz-Chl-Ser, Qz-Bt-Ser, Qz-Ser-Bt); 2 - essentially biotite schists (Bt, Qz-Bt, Chl-Bt); 3 essentially chlorite schists (Chl, Bt-Chl, Cb-Chl); 4 - essentially amphibole schists (Cum, Grt-Cum, Grt-Bt-Cum, Bt-Cum, ChlCum); 5 - the trend of composition changes.

Наявність такого зв'язку говорить про те, що принаймні для найбільш залізистих і найменш глиноземистих сланців (куммінгтонітових), що тісно асоціюють із хемогенними залізисто-кременистими шарами, може мати місце первинно хемогенне осадження 3 колоїдів. На можливість хоча б частково хемогенного осадження глинозему в залізистих кварцитах вказує
А.А. Дроздовська [15]. Про це ж пише Б.О. Горлицький [20], судячи з крайньої збіднілості залізисто-силікатних сланців елементами-домішками (за винятком $\mathrm{Ge}$ i $\mathrm{Mn}$ ).

До первинно кластогенних у чистому вигляді осадів (метаалевропелітів) можна віднести алюмосилікатні i, можливо, деяку частину залізисто-силікатних 
сланців. Основна ж маса залізисто-силікатних сланців саксаганської світи накопичувалася в результаті змішаної кластогенно-хемогенної седиментації (тонкі метапеліти та метаколоїди).

Факторний і кластерний аналізи, проведені за шістьма компонентами $\left(\mathrm{SiO}_{2}, \mathrm{Al}_{2} \mathrm{O}_{3}, \mathrm{Fe}_{2} \mathrm{O}_{3}+\mathrm{FeO}, \mathrm{MgO}\right.$, $\mathrm{CaO}, \mathrm{Na}_{2} \mathrm{O}+\mathrm{K}_{2} \mathrm{O}$ ), дозволяють розділити всю сукупність сланців саксаганської світи на дві найбільш загальні петрохімічні групи (алюмосилікатні і залізисто-силікатні сланці), кожна з яких поділяється, у свою чергу, на дві підгрупи: Al-1, Al-2, F-1, F-2 (рис. 5, таблиця 2).

Залізисто-силікатна група становить 56\% усіх сланців. Підгрупа F-1 (24,2\%) у порівнянні з підгрупою F-2 характеризується підвищеною залізистістю $\left(\mathrm{FeO}+\mathrm{Fe}_{2} \mathrm{O}_{3} \sim 35 \%\right)$ і зниженими величинами $\mathrm{SiO}_{2}$, $\mathrm{Al}_{2} \mathrm{O}_{3}, \mathrm{TiO}_{2}, \mathrm{CO}_{2} \mathrm{H}_{2} \mathrm{O}^{+}$. Мінеральний склад рядових проб істотно амфіболовий (Кумм, Грн-Кумм, Грн-БіКумм). До цієї підгрупи потрапляє велика частина середніх і валових аналізів по сланцевим горизонтам i підгоризонтам; очевидно, що вони відображають змішаний склад як кластогенних, так і хемогенних прошарків. На загальних бінарних діаграмах 3 іншими типами залізистих порід саксаганської світи проби цієї підгрупи розташовуються разом із рудними і малорудними силікатно-магнетитовими джесперами, яшмо-сланцями, тобто знаходяться в полі початкового домінування хемогенної седиментації.

Підгрупа F-2 (31,5\%). У ï складі домінують помірно залізисті сланці із загальним вмістом оксидів заліза 20-28\%. Мінералогічно вони представлені істотно біотитовими, істотно хлоритовими і істотно куммінгтонітовими різностями. Як правило, їм властивий змішаний склад із розвитком усіх зазначених мінералів у різних співвідношеннях. Другорядні мінерали гранат, магнетит, магнезіально-залізистий карбонат. Хлоритові сланці збагачені карбонатом частіше. Мінералогічні різновиди в межах підгрупи F-2 між собою строго не розрізняються так, щоб їм відповідали окремі кластери меншого рангу, зважаючи на неможливість строгого кількісного урахування мінерального складу сланців. Тому зазначені вище в таблиці 1 середні значення різних мінералогічних типів сланців не цілком відповідають реальним літологопетрохімічним спільнотам. Вірогідно, біотитові, хлоритові і куммінгтонітові різності сланців підгрупи F-2 необхідно розглядати спільно, з огляду на близькість їх хімічного складу.

Алюмосилікатна група (44\%) також поділяється на дві підгрупи (Al-1, Al-2), однак менш контрастно, ніж це властиво залізисто-силікатній групі. Краще проявлена найменш фемічна і найбільш сіалічна підгрупа Al-1 (13,7\%), складена сланцями переважно кварцсерицитового складу з підлеглою роллю біотиту, хлориту і домішкою дрібнозернистої графітової речовини. Друга підгрупа Al-2 (27,3\%) несе ознаки переходу від алюмосилікатних глиноземистих сланців Al-1 до залізисто-силікатних F-2, залишаючись у цілому в межах алюмосилікатної групи. У іiї складі поряд з істотно серицитовими сланцями, що переважають, з'являються істотно біотитові і хлоритові, в яких серицит підпорядкований кількісно. У вигляді домішки відзначається тонкодисперсна графітова речовина. У більш метаморфізованих різностях присутні гранат, ставроліт, мусковіт.

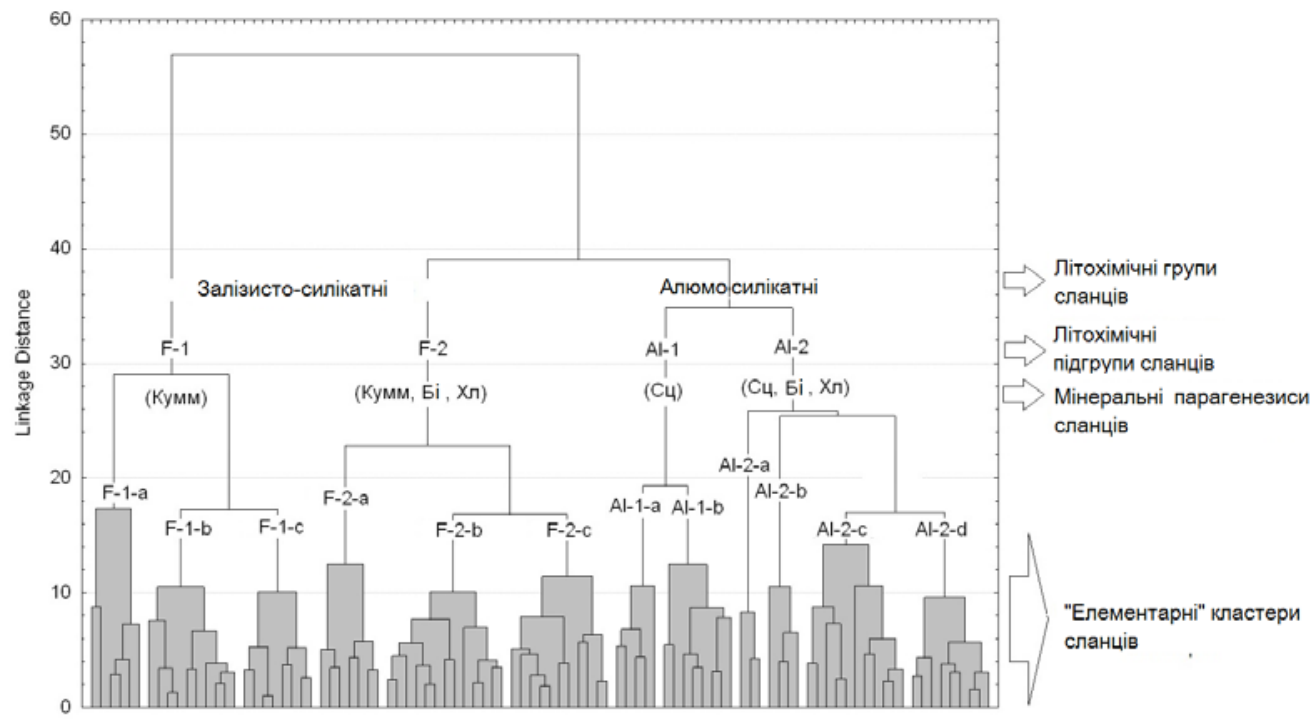

Pис. 5. Дендрограма сланцевих порід саксаганської світи (метод повних зв'язків за шістьома компонентами - $\mathrm{SiO}_{2}, \mathrm{Al}_{2} \mathrm{O}_{3}$, $\mathrm{Fe}_{2} \mathrm{O}_{3}+\mathrm{FeO}, \mathrm{MgO}, \mathrm{CaO}, \mathrm{Na}_{2} \mathrm{O}+\mathrm{K}_{2} \mathrm{O}$ ). Позначення мінералів: Кумм - куммінгтоніт, Бі - біотит, Хл - хлорит, Сц- серицит. Позначення кластерів відповідають таким само у таблиці 2.

Fig. 5. Dendrogram of shale rocks of the Saksagan Formation (the method of full bonds in six components $-\mathrm{SiO} 2, \mathrm{Al} 2 \mathrm{O} 3, \mathrm{Fe} 2 \mathrm{O} 3+$ $\mathrm{FeO}, \mathrm{MgO}, \mathrm{CaO}, \mathrm{Na} 2 \mathrm{O}+\mathrm{K} 2 \mathrm{O}$ ). Abbreviations for minerals: Cum - cummingtonite, $\mathrm{Bt}$ - biotite, Chl - chlorite, Ser - sericite. The cluster symbols correspond to those in table 2. 
Таблиця 2. Хімічний склад (ваг. \%) порід залізисто-кременисто-сланцевої формації саксаганської світи Кривбасу

Table 2. The chemical composition (wt.\%) of rocks of the Saksagan iron-siliceous-shale Formation of the Kryvyi Rig Basin

\begin{tabular}{|c|c|c|c|c|c|c|c|c|c|c|c|c|c|c|c|c|c|c|c|c|}
\hline $\begin{array}{l}\text { № } \\
\text { I/II }\end{array}$ & $\begin{array}{c}\text { Породні класте- } \\
\text { ри }\end{array}$ & $\begin{array}{c}\text { Кільк. } \\
\text { ан. }\end{array}$ & $\mathrm{SiO}_{2}$ & $\mathrm{TiO}_{2}$ & $\mathbf{A l}_{2} \mathbf{O}_{3}$ & $\mathrm{Fe}_{2} \mathrm{O}_{3}$ & $\mathrm{FeO}$ & MnO & MgO & $\mathrm{CaO}$ & $\mathrm{Na}_{2} \mathrm{O}$ & $\mathbf{K}_{2} \mathbf{O}$ & $\mathbf{P}_{2} \mathbf{O}_{5}$ & $\mathrm{~S}$ & $\mathrm{SO}_{3}$ & $\mathrm{CO}_{2}$ & С-віл. & $\mathrm{H}_{2} \mathrm{O}^{-}$ & $\mathrm{H}_{2} \mathbf{O}^{+}$ & Сума \\
\hline 1 & Див. примітку & 23 & 39,73 & 0,04 & $\mathbf{0 , 7 7}$ & 34,84 & 18,19 & 0,13 & 2,18 & 1,29 & 0,21 & 0,16 & 0,18 & & 0,10 & 2,30 & & 0,20 & 0,80 & 101,14 \\
\hline 2 & $"$ & 31 & 43,86 & $\mathbf{0 , 0 7}$ & 2,23 & 23,70 & 21,08 & 0,12 & 3,27 & 1,19 & 0,26 & 0,20 & 0,17 & & 0,26 & 2,75 & & 0,19 & 1,32 & 100,67 \\
\hline 3 & $"$ & 57 & 47,93 & 0,12 & 3,36 & 15,47 & 21,51 & 0,16 & 3,55 & 1,07 & 0,20 & $\mathbf{0 , 5 0}$ & $\mathbf{0 , 1 7}$ & & 0,29 & 4,07 & & 0,18 & 1,66 & 100,24 \\
\hline 4 & $\begin{array}{c}\text { Група сланців- } \\
\text { (F) }\end{array}$ & 53 & 47,36 & 0,26 & 8,76 & 8,15 & 22,21 & 0,14 & 4,42 & 0,62 & 0,33 & 1,35 & 0,15 & 0,27 & 0,24 & 3,24 & 0,41 & 0,19 & 3,10 & 101,20 \\
\hline 5 & Підгруиа F-1 & 23 & 43,18 & 0,28 & 7,61 & 9,20 & 26,15 & 0,13 & 4,76 & 0,73 & 0,19 & 0,81 & 0,15 & & 0,29 & 4,75 & & 0,12 & 2,08 & 100,44 \\
\hline 6 & Кластер F-1/a & 6 & 32,72 & 0,45 & 12,12 & 4,06 & 31,01 & 0,13 & 7,44 & 0,28 & 0,20 & 0,78 & 0,08 & & 0,07 & 8,63 & & 0,12 & 2,6 & 100,69 \\
\hline 7 & Кластер F-1/b & 10 & 44,53 & 0,33 & 8,76 & 10,36 & 23,35 & 0,14 & 3,53 & 0,73 & 0,14 & 0,98 & 0,16 & & 0,51 & 3,68 & & 0,24 & 3,01 & 100,43 \\
\hline 8 & Кластер F-1/c & 8 & 49,73 & 0,22 & 2,70 & 10,73 & 26,80 & 0,11 & 4,36 & 1,08 & 0,20 & 0,68 & 0,23 & & 0,19 & 2,10 & & 0,07 & 1,75 & 100,95 \\
\hline 9 & Підгруnа F-2 & 30 & 54,06 & 0,23 & 8,69 & 6,58 & 18,08 & 0,15 & 4,02 & 0,55 & 0,39 & 1,45 & 0,14 & 0,29 & 0,40 & 1,97 & 0,52 & 0,19 & 3,18 & 100,87 \\
\hline 10 & Кластер F-2/a & 7 & 61,84 & 0,21 & 8,28 & 4,44 & 15,49 & 0,14 & 3,81 & 0,55 & 0,35 & 0,78 & 0,16 & 0,16 & 0,88 & 2,00 & 0,4 & 0,16 & 1,87 & 101,51 \\
\hline 11 & Кластер F-2/b & 13 & 53,37 & 0,17 & 5,64 & 8,60 & 19,39 & 0,19 & 3,65 & 0,59 & 0,23 & 1,04 & 0,19 & 0,46 & 0,25 & 2,56 & 0,41 & 0,17 & 2,81 & 99,72 \\
\hline 12 & Кластер F-2/c & 11 & 49,86 & 0,33 & 12,28 & 5,73 & 18,29 & 0,13 & 4,56 & 0,49 & 0,61 & 2,41 & 0,09 & 0,21 & 0,18 & 0,89 & & 0,26 & 4,55 & 100,86 \\
\hline 13 & $\begin{array}{c}\text { Група сланців } \\
\text { (Al) }\end{array}$ & 42 & 57,54 & 0,45 & 17,55 & 3,91 & 8,31 & $\mathbf{0 , 0 7}$ & 3,00 & 0,52 & 0,99 & 3,36 & 0,10 & 0,33 & 0,47 & 0,70 & 0,68 & $\mathbf{0 , 1 7}$ & 2,70 & 100,85 \\
\hline 14 & Підгруиа Al-1 & 13 & 62,73 & 0,50 & 18,73 & 2,71 & 4,15 & 0,05 & 1,68 & 0,69 & 0,81 & 4,12 & 0,04 & & 0,13 & 0,73 & 0,91 & 0,12 & 0,96 & 99,07 \\
\hline 15 & Кластер Al-1/a & 5 & 65,03 & 0,48 & 14,35 & 3,14 & 5,27 & 0,08 & 2,14 & 0,85 & 0,89 & 4,64 & 0,04 & & & 0,72 & 1,06 & 0,13 & 0,58 & 99,39 \\
\hline 16 & Кластер Al-1/b & 8 & 61,30 & 0,56 & 21,48 & 2,42 & 3,47 & 0,03 & 1,30 & 0,58 & 0,63 & 4,32 & 0,05 & & 0,13 & 0,74 & 0,84 & 0,11 & 1,74 & 99,68 \\
\hline 17 & Підгрупа Al-2 & 26 & 52,91 & 0,45 & 18,64 & 4,94 & 9,35 & 0,08 & 3,43 & 0,42 & 1,11 & 3,42 & 0,12 & 0,36 & 0,33 & 0,58 & 0,37 & 0,21 & 4,02 & 100,74 \\
\hline 18 & Кластер Al-2/a & 3 & 41,13 & 0,45 & 19,48 & 2,47 & 22,68 & 0,07 & 4,24 & 0,32 & 0,50 & 4,11 & 0,11 & 0,08 & 0,04 & 0,12 & & 0,21 & 4,01 & 100,00 \\
\hline 19 & Кластер Al-2/b & 4 & 48,95 & 0,65 & 26,77 & 2,30 & 7,69 & 0,05 & 2,07 & 0,38 & 0,21 & 5,07 & 0,05 & 0,28 & 0,08 & 0,17 & 0,18 & 0,21 & 5,35 & 100,43 \\
\hline 20 & Кластер Al-2/с & 11 & 53,78 & 0,37 & 15,13 & 5,40 & 11,15 & 0,13 & 4,60 & 0,38 & 0,81 & 3,11 & 0,13 & 0,14 & 0,35 & 1,18 & & 0,31 & 4,08 & 101,05 \\
\hline 21 & Кластер Al-2/d & 9 & 56,46 & 0,60 & 18,83 & 3,95 & 7,36 & 0,03 & 2,29 & 0,54 & 0,88 & 3,73 & 0,14 & 0,48 & 0,60 & 0,34 & 0,55 & 0,17 & 3,64 & 100,59 \\
\hline
\end{tabular}

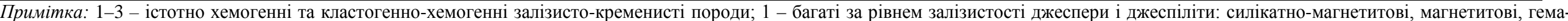

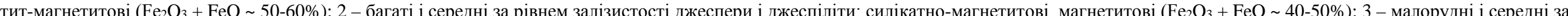

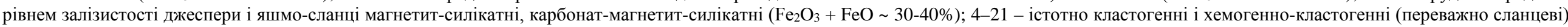

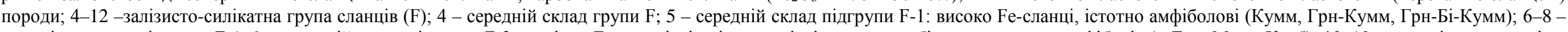

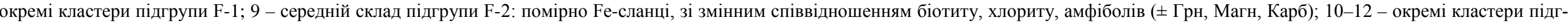

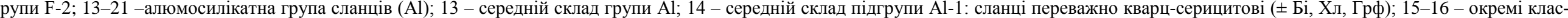
тери підгрупи $\mathrm{Al}-1 ; 17$ - середній склад підгрупи $\mathrm{Al}-2$ : сланці зі змінними співвідношеннями серициту, біотиту і хлориту ( \pm Грн, Ствр, Грф); $18-21$ - окремі кластери підгрупи Аl-2.

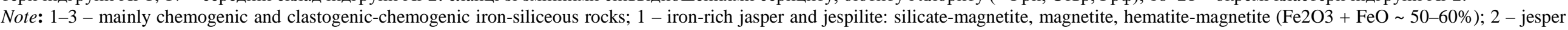

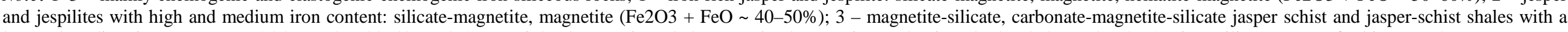

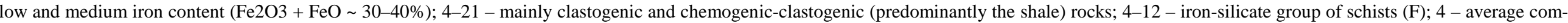

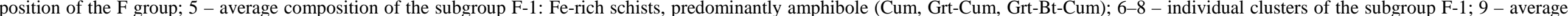

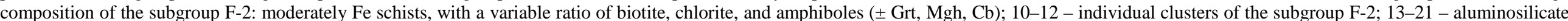

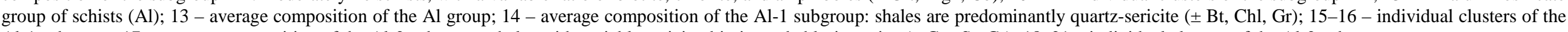
Al-1 subgroup; 17 - average composition of the Al-2 subgroup: shales with variable sericite, biotite and chlorite ratios ( \pm Grt, St, Gr); 18-21 - individual clusters of the Al-2 subgroup 
Зазначені підгрупи поділяються кожна, у свою чергу, ще на 2-4 менших кластери в форматі «елементарних» кластерів (усього 12), які, однак, мінералогічно строго не індивідуалізовані і формують окремі згущення фігуративних точок у складі петрохімічних груп і підгруп, утворюючи таким чином їх внутрішню структуру або «хмари розсіювання». Середній склад петрохімічних груп, підгруп і «елементарних» кластерів наведено в таблиці 2.

У складі залізисто-силікатної підгрупи F-1 дещо відокремлене положення займає кластер F-1-a, якому властивий підвищений вміст магнезіальнозалізистих карбонатів (середні величини $\mathrm{CO}_{2}, \mathrm{FeO}$, $\mathrm{MgO}$ підвищені, відповідно: 11,$5 ; 31 ; 7,5 \%$ ) при загальній високій залізистості, підвищеній глиноземистості і мінімальних величинах $\mathrm{SiO}_{2}$. Серед алюмосилікатних сланців слід особливо відзначити нечисленний високоглиноземистий кластер Al-2-b, для якого характерним $є$ найбільш високий вміст глинозему (25-31\%), а також максимальні величини $\mathrm{TiO}_{2} \mathrm{i}$ $\mathrm{K}_{2} \mathrm{O}$. Цей кластер аналогічний за своїм складом філітовидним кварц-серицитовим сланцям верхньої підсвіти скелюватської світи, що підстеляє залізорудну саксаганського світу. Такі сланці сформовані при розмиванні і ближньому перевідкладенні високозрілої континентальної кори хімічного вивітрювання і $є$ прямим індикатором мілководних умов седиментації. Присутність їх усередині залізорудної формації практично у складі всіх сланцевих горизонтів вказує, по-перше, на парагенетичний зв'язок залізонакопичення 3 протогумідною континентальною корою вивітрювання, по-друге, на незмінно компенсований i, в цілому, мілководний характер седиментації.

\section{Фаціальні умови накопичення залізисто- кременисто-сланцевої формації саксаганської світи}

В літературі $з$ залізисто-кременисто-сланцевих формацій криворізького типу відомо кілька варіантів фаціальні-генетичної інтерпретації аутигенномінералогічної і аутигенно-геохімічної зональності цих комплексів.

Згідно Г. Джеймса [42], у залізорудній формації оз. Верхнього у Північній Америці, що є близьким аналогом формацій криворізького типу, виділяються чотири основні залізисті фації (від берега вглиб басейну): 1 - окисна (гематитова і магнетитова), 2 силікатна, 3 - карбонатна, 4 - сульфідна. Відмінною рисою гематитової фації оз. Верхнього від криворізьких порід є присутність оолітових структур. За Г. Джеймсом, гематитова окисна фація $є$ найбільш мілководною, що відклалася на мілинах в добре аерованих водах; навпаки, породи сульфідної фації займають найбільш глибоководне положення на профілі дна басейну.

Близькі до цих поглядів уявлення I.M. Бордунова $[4,16]$ щодо накопичення саксаганської світи Кременчуцького району: червоноколірні (окисні) фації накопичувалися в умовах мілководдя; глибоководнішим умовам відповідали сіроколірні фації; при цьому найбільш глибоководними були колчеданові відклади, що формуються у відновлювальних умовах i асоціюють 3 сіроколірними магнетитсилікатними джесперами і хлоритовими сланцями; на відміну від Г. Джемса, максимальні глибини, за I.М. Бордуновим, відповідали океанським (до 24 км).

Інше трактування фаціальних умов у М.О. Плаксенка [26] для формації залізистих кварцитів курської серії КМА: найбільш багаті залізом тонкополосчаті червоноколірні (гематитвмісні) гематит-магнетитові і магнетит-гематитові кварцити накопичувалися в найбільш віддалених від берегової лінії і найбільш глибоководних умовах; при цьому загальна глибина басейну була незначною (не більше 200-300 м) при дуже пологому рельєфі дна і рівнинному рельєфі прилеглих континентальних областей.

Як доказ більш глибоководних умов седиментації гематитових кварцитів у порівнянні з магнетитовими кварцитами i безрудними фаціями М.О. Плаксенко використовує аналіз потужностей. Ним установлено закономірний зв'язок між мінеральними видами залізистих кварцитів і потужностями товщ, які вони складають: зі збільшенням загальної потужності товщі залізистих кварцитів у іiі складі збільшується питома вага гематитвмісних кварцитів i, навпаки, зменшується - магнетитових кварцитів. Окрім того, ним встановлено негативну корелятивну залежність між потужностями товщі залізистих кварцитів і сумарними потужностями пластів і прошарків сланців, що знаходяться в ній. Однак такі прямі кореляції між глибиною седиментації і потужностями осадів, на наш погляд, не зовсім коректні, як, наприклад, не є доказом глибоководних умов великі потужності континентальних грубоуламкових молас.

Іншою ознакою, що свідчить, на думку М.О. Плаксенка, про більш глибоководні умови багатих залізистих кварцитів i, особливо, гематитвмісних різновидів, є характер розподілу глинозему в залізистих кварцитах, вміст якого закономірно знижується від середини сланцевих до середини залізистих горизонтів, досягаючи мінімальних значень у найбільш багатих гематитових джеспілітах: «величина содержания глинозема в железистых кварцитах указывает на степень засоренности их первичных 
осадков пелитовыми образованиями, т.е. на относительную удаленность участка седиментации от береговой линии или, иначе, на их относительную глубоководность» [26, с.117]. Однак, віддаленість від берегової лінії не завжди означає більш глибоководні умови. У великих мілководних внутрішньоконтинентальних басейнах, у їх центральних віддалених від берега зонах, куди обмежений приплив кластогенного матеріалу, можуть знаходитися широкі мілини, пов’язані з підняттям дна басейну седиментації.

Літохімічні і геологічні характеристики порід залізисто-кременисто-сланцевої формації саксаганської світи Кривбасу дають підстави судити про ці породи як про фації великого мілководного басейну 3 досить пологим рельєфом дна басейну седиментації і навколишніх областей.

У залізистих червоноколірних породах Кременчука у складі дванадцятої пачки першої кременчуцької світи [16] спостерігається тонке перешарування залізистих джесперів із пісковиками і світлими серицитовими сланцями - явище унікальне для всієї Криворізько-Кременчуцької структурноформаційної зони (КСФЗ). Воно доводить можливість близької за часом седиментації і перешарування високозрілих у хімічному відношенні теригенних псаміт-алевро-пелітів і хемогенних гематитвмісних залізистих джесперів. Оскільки перші є критерієм мілководності і близькості берегової лінії, то такі ж умови могли існувати і при седиментації залізистих джесперів.

Виявлені в Кременчуцькій структурі колчеданні пласти всередині криворізької серії також є рідкісними утвореннями для всієї КСФЗ [16]. Пласти і шари колчеданів потужністю до 0,6 м знаходяться в перешаруванні з хлорит-карбонатними джесперами і біотит-серицитовими сланцями. За вмістом $\mathrm{Fe}_{\text {заг }}$ (у середньому $31,6 \%$ ) колчедани близькі до сіроколірних карбонатних джесперів. За I.М. Бордуновим [16], крайнє положення колчеданів у трансгресивному ряді залізистих геохімічних фацій (червоноколірної, сіроколірної, колчеданної) вказує на їх утворення в умовах максимальних глибин накопичення осадів, які оцінено I.М. Бордуновим в 2-4 тис. м (тобто океанічні глибини), виходячи лише 3 припущення про некомпенсоване прогинання під час седиментації саксаганської світи. Однак численні літолого-фаціальні ознаки порід саксаганської світи 3 очевидністю свідчать про протилежне - незмінно компенсоване осадонакопичення. До числа таких ознак можна віднести присутність у складі практично всіх стратиграфічних рівнів саксаганської світи порід, які є індикаторами мілководної седиментації - високозрілих метапелітів кварц-серицітового складу, а в Кременчуцькій структурі ще і зрілих ка- лішпат-кварцових метапісковиків та метаалевролітів. Про це ж свідчать і внутрішньоформаційні перерви, пов'язані з локальним осушенням і виводом басейну із зони седиментації з наступним відкладенням базальних псаммоалевритових шарів і прошарків внутрішньоформаційних літитових апопелітових конгломератобрекчій. На півдні Кременчуцької структури дев'ята пачка першої кременчуцької світи, у складі якої встановлено невеликі пласти і лінзи колчеданів, виклинюється, зрізуючись стратиграфічним внутрішньформаційним неузгодженням; в основі пачки, що лежить вище, розвинені малопотужні конгломерати з уламками колчеданів, залізистих джесперів і сланців. Це підтверджує в цілому мілководну седиментацію, в тому числі і самих колчеданів. Найбільші глибини басейну, ймовірно, не перевищували 100 м.

Фундаментальною особливістю хімізму залізисто-кременистих порід КСФЗ, успадкованою від вихідних осадів, є характер розподілу в них значень ступеня окислення заліза $\mathrm{Fe}_{2} \mathrm{O}_{3} / \mathrm{FeO}$. Найбільш залізисті і водночас найменш глиноземисті (збіднені на кластогенний пелітовий матеріал) різновиди порід ЗКФД - тонкополосчаті магнетитові і гематитмагнетитові джеспіліти - мають підвищені значення цього коефіцієнта $-\mathrm{Fe}_{2} \mathrm{O}_{3} / \mathrm{FeO}$ в них значно вищий, ніж в малорудних магнетит-силікатних джесперах i залізисто-силікатних сланцях. Дана фундаментальна петрохімічна ознака разом із текстурноструктурними характеристиками (характером шаруватості) порід вказує на цілком певні фаціальні особливості накопичення багатих залізорудних фацій: в першу чергу, на більш окислювальний характер середовища седиментації по відношенню до джесперів і залізисто-силікатних сланців; по-друге, на дуже спокійні умови седиментації, (ймовірно, нижче хвильового базису), а також на відсутність або дуже незначний притік теригенних осадів, що можливо при рівнинному рельєфі суміжних континентальних областей зносу або за наявності обмежувального бар'єру у вигляді підводних барів і мілин (або того і іншого). Такі умови могли реалізуватися в умовах стабільного мілководного шельфу, широких напівзамкнутих лагун або озер з обмеженим припливом теригенних суспензій (на значній відстані від берегової лінії в межах мілководних банок, або поблизу берега за дуже незначним привносом теригенних осадів).

Гумідний (теплий і вологий) клімат у період формування залізорудної формації саксаганської світи доводиться синхронністю процесів сіалітного вивітрювання на суші і седиментації залізисто-силікатнокременистих осадів. Це встановлено за відомими фактами залягання залишкового сіалітного метаелювію на плагіогранітах фундаменту безпосередньо 
під осадами першого сланцевого горизонту саксаганської світи і філітами та метапісковиками скелюватської світи в межах рудника ім. Дзержинського $[9,30,36]$, а також неподалік - на території рудника ім. Кірова [2, 9, 14, 36] і рудника ім. Ілліча [2]. Гумідні (в цілому) умови на етапі седиментації ЗКФД підтверджуються і рядом інших ознак: приналежністю порід ЗКФД до гумідного серіального петрохімічного типу [28, 29], присутністю у складі всіх сланцевих горизонтів саксаганської світи прошарків високоглиноземистих (високозрілих) метапелітів. Поряд 3 уявленнями про гумідний тип літогенезу існують також припущення щодо існування періодів, близьких до евапоритової седиментації, котрі засновані на присутності рибекіт- і егіринвмісних прошарків у шостому і сьомому залізистих горизонтах саксаганської світи Криворіжжя, а також у верхах залізорудних світ Кременчуцького басейну i Михайлівського району КМА. Розподіл лужних амфіболів при цьому підпорядковується загальній мікроритмічності залізисто-кременистих порід. B.I. Скаржинський у 1958 р [35] висловив цілком обгрунтоване припущення про те, що деякі різновиди кварцитів шостого і сьомого залізистих горизонтів містять лужний амфібол, що має аутигенну природу і утворився не в результаті процесів метасоматозу, а при метаморфизмі шарів, початково збагачених натрієм.

Про походження метаосадових стільпномелан- та рибекітвмісних залізисто-кременистих порід у докембрійських комплексах світу відомі уявлення, засновані як на впливі вулканогенних процесів (перевідкладення попілового матеріалу, фумарольносольфатарні процеси) [22], так і на впливі евапоритових умов басейну седиментації $[6,43]$. У залізорудних формаціях докембрію Південної Африки, зокрема формації Куруман (трансваальська система), встановлено стратиграфічний контроль концентрацій натрію (рибекітових шарів) всередині залізистих порід, що свідчить про те, що натрій концентрувався в певні моменти часу седиментації в умовах мілководдя. Такий же зв'язок концентрацій натрію в залізистих породах встановлюється і в інших регіонах формації Грікватаун-Джаспер (Пд. Африка) та ін. [5].

За даними М.О. Ярощук, В.Л. Онопрієнка [40], підвищена лужність осадів шостого і сьомого залізистих горизонтів пояснюється участю туфогенного попілового матеріалу, хоча не виключається і існування евапоритових умов із підвищенням солоності басейну. Літохімічні дані, наведені нами в наявній статті, свідчать на користь туфогенної версії, оскільки в залізистих осадах не відзначається загальної тенденції збільшення вмісту натрію, що неминуче мало б місце $з$ наростанням евапоритових умов. Пі- двищений вміст натрію в залізистих кварцитах має епізодично-випадковий характер.

Обстановка седиментації залізисто-кременистосланцевої формації саксаганської світи найближче нагадує мілководні платформні морські (стабільний шельф) або великі внутрішньократонні мульдоподібні мілководні озерні басейни. За даними Ю.П. Мельника, [21], глибина басейну не могла бути більше перших сотень метрів, оскільки в іншому випадку гідроксиди та карбонати $\mathrm{Fe}$, що випали в верхніх шарах води, розчинялися б, не доходячи дна. Мінімальна ж глибина для ритмічно-шаруватих ЗКФД (Кривий Ріг, КМА, Хамерслі) навряд чи була меншою хвильового базису (20-30 м). Детальне вивчення шаруватих текстур ЗКФД Кривбасу Л.Я. Ходюш [38], Д.О. Куликом [18, 19] дійшло висновку про виключно спокійні мілководні умови седиментації і активні процеси діагенетичного перетворення залізисто-кременистих осадів. Глибини накопичення осадів були в цілому невеликими, однак більше за хвильовий базис (50-70 м).

Сучасна витягнута складноскладчаста геологічна будова басейну не зберігає його первісної форми i розмірів. Басейн характеризувався досить рівним рельєфом дна і прилеглих територій, а седиментація мала компенсований характер. Водночас окремі ділянки, розмежовані конседиментаційними розломами, зазнавали прогинання різної інтенсивності, що призвело до поділу басейну на локальні мульдоподібні депресії.

Незаперечним фактом широкої площинної седиментації ЗКФД палеопротерозою $є$ басейн Хаммерслі в Західній Австралії. Породи залягають субгоризонтально на величезній площі, до того ж окремі шари простежуються без істотних змін на відстані багатьох десятків км.

На думку М.О. Плаксенка [26], характер літогенезу осадів курської серії свідчить про пасивність тектонічних процесів, досить пологий і рівнинний рельєф дна басейну седиментації і найбільш відповідає областям з субплатформним режимом.

Згідно з реконструкцією I.М. Щеголева [39], масштаб загального субплатформного КурськоКриворізького басейну седиментації залізистокременистих утворень за розмірами не поступався ранньопротерозойській водоймі Хаммерслі. Ширина припустимого басейну становила 350-400 км, а довжина в північно-західному напрямку - приблизно 600-700 км. Для порівняння, ширина Каспійського моря - 300 км, довжина -1200 км.

Субплатформний режим і широкий площинний характер накопичення залізисто-кременистих осадів палеопротерозою відкриває можливості для міжрегіональних міжмегаблокових стратиграфічних кореляцій в докембрії УЩ. 


\section{Висновки}

1. На основі проведеної літохімічної типізації виділено 12 «елементарних» кластерів для сланцевих порід залізисто-кременисто-сланцевої формації, розділених між двома літохімічними групами і чотирма підгрупами, індивідуалізованими за мінеральним складом. Позначено відповідності між літохімічними і мінеральними типами сланцевих порід формації.

2. Якісні оцінки кореляцій породоутворюючих компонентів підтверджують первинно осадовий теригенно-хемогенний генезис порід залізистокременисто-сланцевої формації Кривбасу.

3. Сукупності літохімічних типів порід утворюють закономірну послідовність, яка відповідає аутигенно-мінеральній і вихідній аутигеннолітофаціальній зональності відкладів, тобто представляє собою послідовний ізоморфний фаціальний ряд/профіль осадів від чисто кластогенних до чисто хемогенних: алюмосилікатні, в тому числі високоглиноземисті метапеліти $\rightarrow$ залізисто-силікатні метапеліти, часто карбонатисті $\rightarrow$ малорудні і середні за рівнем залізистості джеспери і яшмо-сланці, здебільшого сірополосчаті, часто карбонатисті $\rightarrow$ багаті за рівнем залізистості джеспери і джеспіліти, в тому числі червонополосчаті. Запропоновано емпіричну класифікаційну діаграму вказаної послідовності порід залізисто-кременисто-сланцевої формації в координатах $\mathrm{Al}_{2} \mathrm{O}_{3} \mathrm{i}\left(\mathrm{Fe}_{2} \mathrm{O}_{3}+\mathrm{FeO}\right)$ за розділенням на області кластогенної, кластогенно-хемогенної і хемогенної седиментації. Найбільш багаті залізом породи - вторинно неокислені червонополосчаті джеспіліти - характеризуються найвищим співвідношенням $\mathrm{Fe}_{2} \mathrm{O}_{3} / \mathrm{FeO}$, що вказує на їх утворення в мілководних добре аерованих умовах.

4. Літохімічні ознаки порід у комплексі з особливостями їх залягання, стратифікації і поширення підтверджують в цілому протогумідний тип літогенезу залізисто-кременисто-сланцевої формації палеопротерозою Кривбассу в умовах рівнинних мілководних басейнів. Останнє передбачає субплатформний тектонічний режим седиментації.

\section{Література}

1. Белевцев Я.Н. Стратиграфия и тектоника Криворожского бассейна // Сов.геология. 1946. Вып. 11. С. 3-24.

2. Бондаренко П.М., Горошников Б.И., Кулишов П.М., Кучер В.Н. О взаимоотношении Криворожской метаморфической серии и саксаганских плагиоклазовых гранитов // Геология и горное дело. Сб. науч. тр. н.-и горнорудн. ин-та. Сер.геол. № 2. М: Металлургиздат, 1959. С. 132-142.

3. Бордунов И.Н. Геология Кременчугского железорудного района. К.: Наук.думка, 1964. 217 с.

4. Бордунов И.Н. Колчеданы Кременчугского района // Геохимия и рудообразование. 1976. Вып. 5. С. 69-73.
5. Бьюкс Н. Дж. Докембрийские железорудные формации Африки / Докембрийские железорудные формации Мира. М.: «Мир», 1975. С. 70-128.

6. Геер Дж. Железорудные месторождения штата Мичиган / Геология и генезис докембрийских железистокремнистых и марганцевых формаций мира (Труды Международного симпозиума). Киев: Наукова думка, 1972. С. 370-375.

7. Геология криворожских железорудных месторождений / Ред. кол: Я.Н. Белевцев, Г.В. Тохтуев, А.И. Стрыгин и др. Киев: Изд.-во АН УССР, 1962. Т. 1. 484 с.; Т. 2. $566 \mathrm{c}$.

8. Гершойг Ю.Г., Грицай Ю.Л., Педан М.В., Шапошников В.А. Стратиграфическое расчленение и особенности руд четвертого железистого горизонта в Кривбассе // Геол. рудн. месторождений. 1972. № 5. С. 98-107.

9. Гершойг Ю.Г. Каплун Е.Я. Древняя метаморфизованная кора выветривания магматогенных пород Криворожского бассейна // Докл. АН СССР. 1970. Т. 195. № 4. C. 915-918.

10. Грицай Ю.Л., Педан М.В., Дмитриев Э.В., Шапошников В.А. Цикличность в породах железистых горизонтов средней свиты Кривбасса / Перспективы развития железных руд Криворожского бассейна на глубину. К.: Наук.думка, 1975. С. 19-26.

11. Дмитриев Э.В., Черновский М.И., Шапошников В.А. О цикличности и слоистости в толще железистых кварцитов Скелеватского магнетитового месторождения в Криворожском бассейне // Литол. и полезн. ископ. 1974. № 3. C. 100-107.

12. Доброхотов М.Н. Геология и железные руды Кременчугского района. М.: Недра, 1964. 221 с.

13. Доброхотов М.Н. Геология железисто-кремнистых формаций Кременчугского района / Геология железистокремнистых формаций Украины. К: Изд. АН УССР, 1959. C. 213-263.

14. Додатко А.Д., Кухарева Н.И., Семергеева Е.А. Новые данные о древней метаморфизованной коре выветривания магматических пород Саксаганского района Кривбасса // Изв. АН СССР. Сер.геол. 1972. № 5. С. 126137.

15. Дроздовская А.А. Некоторые геологические приложения физико-химической модели глобального железонакопления в раннем протерозое // Докл. АН СССР. 1986. T. 287. №2. С. 418-422.

16. Железисто-кремнистые формации Украинского щита / Под ред. Н.П. Семененко. Киев: Наук.думка, 1978. T. 1.326 c. T. 2.367 c.

17. Железисто-кремнистые формации докембрия. Железонакопление в докембрии. Киев: Наукова думка, 1992. $228 \mathrm{c}$.

18. Кулик Д.А. Условия образования полосчатых текстур железистых кварцитов саксаганской свиты Криворожского бассейна. Киев: Препринт ИГФМ АН УССР, $1986.65 \mathrm{c}$.

19. Кулик Д.А. Рудообразующие факторы литогенеза железисто-кремнистых формаций / Железистокремнистые формации докембрия. Железонакопление в докембрии. Киев: Наукова думка, 1992. С. 75-104.

20. Кулиш Е.А., Горлицкий Б.А. Петрохимия докембрийских комплексов Украинского и Алданского щитов. Киев: Наук.думка, 1989. 192 с.

21. Мельник Ю.П. Физико-химические условия образования докембрийских железистых кварцитов. Киев: Наук.думка, 1973. 285 с.

22. Мори Г.Б. Железорудные районы Мисаби, Ганфлинт и Куюна в Миннесоте / Геология и генезис докембрийских железисто-кремнистых и марганцевых формаций мира (Труды Международного симпозиума ). Киев: Наук. Думка, 1972. С. 204-221. 
23. Петрография железисто-кремнистых формаций УССР / Н.П. Семененко, Г.В. Жуков, Н.И. Половко и др. К.: Изд-во АН УССР, 1956. 536 с.

24. Пирогов Б.И. Геолого-минералогические факторы, определяющие обогатимость железистых кварцитов. Москва: Недра, 1969. 240 с.

25. Пирогов Б.И. Железисто-кремнистые формации докембрия европейской части СССР. Минералогия Киев: Наукова думка, 1989.168 с.

26. Плаксенко Н.А. Главнейшие закономерности железорудного осадконакопления в докембрии: На примере Курской магнитной аномалии. Воронеж: Изд-во Воронеж.ун-та, 1966. 264 с.

27. Плаксенко Н.А., Коваль И.К. Элементы-примеси в железисто-кремнистых породах докембрия КМА. Воронеж: Изд-во ВГУ, 1981. 216 с.

28. Покалюк В.В. Вулканізм і седиментогенез ранньодокембрійських етапів розвитку КриворізькоКременчуцької структурно-формаційної зони Українського щита / автореф. дис. д-ра геол. наук: 04.00.01. Київ, 2016. 40c.

29. Покалюк В.В. Литогенез в раннем докембрии Криворожского железорудного бассейна. - LAPLAMBERT AcademicPublishing: 2017. - 461 p.

30. Пономарев М.С. Новые данные о соотношении Криворожской метаморфической толщи с саксаганскими плагиоклазовыми гранитами // Докл. АН СССР. 1960. T.133. № 4. C. 917-920.

31. Семененко Н.П. Парагенетический анализ и систематика метаморфических пород / Труды Ин-та геол. наук АН УССР. Серия петр., минер.и геохим. Вып. 2. 1954.

32. Семененко Н.П. Половко Н.И., Жуков Г.В., Ладиева В.Д., Макухина А.А. Петрография железистокремнистых формаций Украинской ССР. Киев: Изд-во АН УCCP, 1956. $535 \mathrm{c}$.

33. Семененко Н.П., Половко Н.И., Грицков Я.М. и др. Геология железисто-кремнистых формаций Украины. Киев: Изд. АН УССР.1959. 688 с.

34. Скаржинская Т.А. Железисто-кремнистая метаконгломерат-песчаниковая (кластогенная) формация. Железисто-кремнистая доломит-метапесчаниково-сланцевая формация / Железисто-кремнистые формации докембрия. Типы формаций. Киев: Наук.думка, 1988. С.110-117.

35. Скаржинский В.И. О некоторых особенностях условий образования щелочных амфиболов в центральной части Криворожского бассейна // Зап. Всесоюзного минер.об-ва. 1958. Ч.87. Вып.2. С. 87-92.

36. Титлянов А.А., Китаев О.В. О возрастном взаимоотношении саксаганских плагиогранитов с породами тальково-карбонатного горизонта // Вопросы подземной и открытой разработки железных руд в Криворожском бассейне. Труды н.и. горнорудн. ин-та. 1967. Сб. 12. С. 204211.

37. Федорченко В.С. Минеральный состав и текстурно-структурные особенности докембрийских железистых пород низкой ступени метаморфизма (фации зеленых сланцев) / Проблемы образования железистых пород докембрия. К., 1969. С. 168-177.

38. Ходюш Л.Я., Кулик Д.А. Ритмическая слоистость докембрийских железорудных образований и модели ее происхождения / Препринт ИГФМ АН УССР. Киев, 1983. $64 \mathrm{c}$.

39. Щеголев И.Н. Раннепротерозойский КурскоКриворожский бассейн седиментации железистокремнистых образований // Геол. журнал. 1984. № 6. С. 122-126.

40 Юдович Я.Э., Кетрис М.П. Основы литохимии. Санкт-Петербург: Наука, 2000. - 479 с.

41. Ярощук М.А., Оноприенко В.Л. Новые данные о минералогии и условиях седиментации железисто- кремнистых пород шестого и седьмого горизонтов Центрального Криворожья // Геохимия и рудообразование. 1973. Вып. 2. С. 31-38.

42. James H.L. Sedimentary facies of iron formation // Econ. Geol. V. 49.№3. 1954.

43. Trendall A.F., Blockley J.G. The iron formations of the Hamersley Group, Western Australia, with spesial reference to the associated crocidolite // West. Australia Geol. Surv. Bull. 1970. V. 119. 353 pp.

\section{References}

1. Belevtsev Ya.N. (1946), Soviet Geology, Iss. 11, Moscow, USSR, pp. 3-24.

2. Bondarenko P.M., Goroshnikov B.I., Kulishov P.M., Kucher V.N. (1959), Geology and Mining,Ser. Geol, No. 2, Metallurgizdat, Moscow, USSR, pp. 132-142.

3. Bordunov I.N. (1964), Geology of the Kremenchug iron ore district, Nauk.dumka, Kiev, USSR, 217 p.

4. Bordunov I.N. (1976), Geochemistry and ore formation, Iss.5, Nauk.dumka, Kiev, USSR, pp. 69-73.

5. B'yuks N. Dzh. (1975), Precambrian iron ore formations of the World, Mir, Moscow, USSR, pp. 70-128.

6. Geyer Dzh. (1972), Geology and Genesis of Precambrian Iron-Siliceous and Manganese Formations of the World, Naukova dumka, Kiev, USSR, pp. 370-375.

7. Belevtsev Ya.N. (1962), Geology of Krivoy Rog iron ore deposits, Ac. of Sc. USSR, Kiev, USSR, V. 1, 484 p, V. 2, $566 \mathrm{p}$.

8. Gershoyg Yu.G., Gritsay Yu.L., Pedan M.V., Shaposhnikov V.A. (1972), Geol. ore deposits, Leningrad, USSR, No. 5. pp. 98-107.

9. Gershoyg Yu.G. Kaplun E.Ya. (1970), Proceedings of the Academy of Sciences of USSR, V. 195, No. 4, Moscow, USSR, pp. 915-918.

10. Gritsay Yu.L., Pedan M.V., Dmitriev E.V., Shaposhnikov V.A. (1975), Prospects for the development of iron ores in the Krivoy Rog basin to a depth. Nauk.dumka, Kiev, USSR, pp. 19-26.

11. Dmitriev E.V., Chernovsky M.I., Shaposhnikov V.A. (1974), Lithology and Mineral Resources, No. 3, Moscow, USSR, pp. 100-107.

12. Dobrokhotov M.N. (1964), Geology and iron ore of the Kremenchug region.Nedra, Moscow, USSR, 221 p.

13. Dobrokhotov M.N. (1959), Geology of iron-siliceous formations of Ukraine.Ac. of Sc. USSR, Kiev, USSR, pp. 213-263.

14. Dodatko A.D., Kukhareva N.I., Semergeeva E.A. (1972), News of the USSR Academy of Sciences, Ser. Geol, No. 5, pp. 126-137.

15. Drozdovskaya A.A. (1986), Proceedings of the Academy of Sciences of USSR, V. 287, No. 2, Moscow, USSR,pp. 418-422.

16. Semenenko N.P. (1978), Iron-siliceous formations of the Ukrainian shield, Nauk. Dumka, .Kiev, USSR, V. 1, 326 p, V. 2, 367 p.

17. Belevtsev Ya.N. (1992), Iron-siliceous Precambrian formations. Iron accumulation in Precambrian, Naukova Dumka, Kiev, UA, 228 p.

18. Kulik D.A. (1986), Conditions for the formation of banded textures of iron quartzites of the Saksaganskaya Formation of the Krivoy Rog basin, Kiev, USSR, 65 p.

19. Kulik D.A. (1992), Iron-siliceous formations of Precambrian. Iron accumulation in Precambrian, Naukova Dumka, Kiev, UA, pp. 75-104.

20. Kulish EA, Gorlitsky B.A. (1989), Petrochemistry of Precambrian complexes of the Ukrainian and Aldan shields, Naukova Dumka, Kiev, USSR, 192 p.

21. Melnik Yu.P. (1973), Physicochemical conditions for the formation of Precambrian ferruginous quartzites, Naukova Dumka, Kiev, USSR, 285 p. 
22. Mori G.B. (1972), Geology and Genesis of Precambrian Iron-Siliceous and Manganese Formations of the World (Proceedings of the International Symposium), Naukova Dumka, Kiev, USSR, pp. 204-221.

23. Semenenko N.P. et al. (1956), Petrography of ironsiliceous formations of the Ukrainian SSR, Publishing House of the Academy of Sciences of the Ukrainian SSR, Kiev, UA, $536 \mathrm{p}$.

24. Pirogov B.I. (1969), Geological and mineralogical factors determining the enrichment of ferruginous quartzites. Nedra, Moscow, USSR, 240 p.

25. Pirogov B.I. (1989), Iron-siliceous Precambrian formations of the European part of the USSR. Mineralogy. Naukova Dumka, Kiev, USSR,.168 p.

26. Plaksenko N.A. (1966), The main laws of iron ore sedimentation in Precambrian: On the example of the Kursk magnetic anomaly.Publishing house of Voronezh.University, Voronezh, USSR, 264 p.

27. Plaksenko N.A., Koval I.K. (1981), Impurity elements in iron-siliceous rocks of Precambrian of the Kursk magnetic anomaly. Publishing House of the Voronezh State University, Voronezh, USSR, 216 p.

28. Pokalyuk V.V. (2016), Volcanism and sedimentogenesis of early Precambrian stages in the development of the Krivyi Rig-Kremenchug structural-formational zone of the Ukrainian Shield, Kiev, UA, 40 p.

29. Pokalyuk V.V. (2017), Lithogenesis of the early Precambrian of the Krivoy Rog iron ore basin. LAPLAMBERTAcademicPublishing, 461p.

30. Ponomarev M.S. (1960), Proceedings of the Academy of Sciences of USSR, V. 133, No. 4, Moscow, USSR, pp. 917920.

31. Semenenko N.P. (1954), Proceedings of the Institute of Geol. Sciences of the Ukrainian SSR. Series petr., miner.and geochem, Vol. 2.
32. Semenenko N.P. Polovko N.I., Zhukov G.V., Ladieva V.D., Makukhina A.A. (1956), Petrography of iron-siliceous formations of the Ukrainian SSR, Publishing House of the Academy of Sciences of the Ukrainian SSR, Kiev, USSR, 535 p.

33. Semenenko N.P., Polovko N.I., Gritskov Y.M. (1959), Geology of iron-siliceous formations of Ukraine, Publishing House of the Academy of Sciences of the Ukrainian SSR, Kiev, USSR, 688 p.

34. Skarzhinskaya T.A. (1988), Iron-siliceous Precambrian formations. Types of formations,Naukova Dumka, Kiev, USSR, pp.110-117.

35. Skarzhinsky V.I. (1958), Proceedings of the All-Union Mineralogical Society, Part 87, Issue 2, Leningrad, USSR, pp. 87-92.

36. Titlyanov A.A., Kitaev O.V. (1967), Issues of underground and open-cast mining of iron ores in the Krivoy Rog basin. Mining Institute Proceedings,No. 12, USSR, pp. 204211.

37. Fedorchenko V.S. (1969), Problems of formation of iron rocks of Precambrian. Kiev, USSR, pp. 168-177.

38. Khodyush L.Ya., Kulik D.A. (1983), The rhythmic layering of Precambrian iron ore formations and models of its origin, Preprint IGFM Ac.Sc. Ukrainian SSR, Kiev, USSR, 64 p.

39. Schegolev I.N. (1984), Geol. Journal. No. 6, Kiev, USSR, pp. 122-126.

40. Yudovich Y.E., Ketris M.P. (2000), Fundamentals of lithochemistry. Nauka, St. Petersburg, 479 p.

41. Yaroshchuk M.A., Onoprienko V.L. (1973), Geochemistry and ore formation, Issue 2, Nauk. dumka, Kiev, USSR, pp. 31-38.

42. James H.L. (1954), Sedimentary facies of iron formation, Econ. Geol, V. 49, No. 3.

43. Trendall A.F., Blockley J.G. (1970), West.Australia Geol. Surv. Bull, V. 119, 353 p.

\section{LITHOCHEMISTRY AND CONDITIONS OF SEDIMENTATION OF THE PALEOPROTEROZOIC IRON-SILICEOUS FOR- MATION OF THE KRIVOY ROG BASIN (UKRAINIAN SHIELD)}

Pokalyuk V., D. Sc. (Geol), Leading Researcher, State Institution «The Institute of Environmental Geochemistry of National Academy of Sciences of Ukraine», ORCID:0000-0002-9282-0246, pvskan@ukr.net

Based on modern lithochemical dataset statistical processing methods, the chemical composition features of the Paleoproterozoic iron ore (ironsiliceous) formation of the Saksagan Formation of the Kryvyi Rig basin of the Ukrainian Shield have been clarified with a view to improve the lithochemical systematics of the Precambrian iron-siliceous formations and to elucidate the general paleogeographic (climatic, facies) conditions of their clastogenic-chemogenic sedimentation. A series of binary diagrams illustrates the relationship between iron-siliceous and shale layers. Using the cluster analysis method, lithochemical typification of shale rocks of the iron-siliceous formation was carried out: 12 "elementary" clusters were distinguished between two lithochemical groups and four subgroups separated by the mineral composition. The correspondence between lithochemical and mineral types of shale rocks has been indicated. The lithochemical types are arranged in a regular sequence, which corresponds to the initial authigenic-mineralogical and authigenic-lithofacial zonality of the sediments and allows, in general, denoting the facies isomorphic series of meta-sediments from metaclastogenic to metachemogenic ones. An empirical classification diagram of rocks in the coordinates $\mathrm{Al} 2 \mathrm{O} 3$ and $\left(\mathrm{Fe}_{2} \mathrm{O}_{3}+\mathrm{FeO}\right)$ is proposed for dividing them into areas of chemogenic, chemogenic-clastogenic, and clastogenic sedimentation. The most iron-rich rocks - secondarily unoxidized red-banded jaspilites - are characterized by the highest $\mathrm{Fe}_{2} \mathrm{O}_{3} / \mathrm{FeO}_{\mathrm{O}} \mathrm{ratio}$, which indicates their formation under shallow, well aerated conditions. The lithochemical features of the rocks in combination with the peculiarities of their occurrence, stratification and distribution confirm, on the whole, the protohumid type of lithogenesis in the conditions of low-lying shallow basins with a subplatform tectonic regime.

Keywords: Paleoproterozoic, Precambrian iron-siliceous formations, Ukrainian shield, Kryvyi Rig iron ore basin, lithochemistry 